\title{
Erzincan Kentinde Yerel Zemin Özelliklerinin Deprem Duyarıı̆ı̆ına Etkisi
}

\author{
Emre Özşahin ${ }^{1, *}$, Ilker Eroğlu1,** \\ ${ }^{1}$ Tekirdağ Namık Kemal Üniversitesi, Fen Edebiyat Fakültesi, Coğrafya Bölümü, Süleymanpaşa, Tekirdağ. \\ *ORCID: 0000-0001-8169-6908, " ORCID: 0000-0003-4601-024X
}

\section{Özet}

Son yıllarda hızlı nüfus artışına bağgl olarak kentlerin kontrolsüz büyümeleri, yerel zemin koşulları bakımından uygunsuz alanlara doğru yönelmelerine neden olmuştur. Aynı zamanda kent merkezlerinde depreme duyarlı alanları eskiye göre arttıran bu durum, yaşanan depremlerin de kent depremi özelliği kazanmasina yol açmıştır. Bu yüzden günümüz kentlerinde, yerel zemin koşullarına dayalı deprem duyarlılık çalışmalarının yapılması zorunluluk haline gelmiştir. CBS (Coğrafi Bilgi Sistemleri) tekniklerinin bir araç olarak kullanıldı̆̆ bu çalışmada, Erzincan kentinde yerel zemin koşullarının deprem duyarlılığına etkisinin frekans oranı yöntemiyle analiz edilmesi amaçlanmıştır. Kentin kurulduğu alanın yerel zemin koşullarl, deprem etkisinin kuvvetli bir şekilde hissedilmesine yol açmaktadır. Çalışma kapsamında kentsel alandaki yerel zemin koşullarına bağlı olarak deprem duyarlılığının dağılımı ve nüfusa yönelik olası etkileri irdelenmistir. Calıșma sonunda 95.596 (2015) kișinin yaşadı̆̆ Erzincan kentinin yüksek deprem duyarlılĭgına sahip olduğu anlaşılmıştır. Deprem duyarlılığının en yüksek olduğu mahalleler, Atatürk, Inönü, Karaağaç, Kızılay ve Yenimahalle'dir. Olası bir deprem anında yerel zemin koşullarından kaynaklanabilecek hasar, deprem duyarliliğının orta derecede olduğu kent çevresindeki alanlarda daha az olacaktır. Bu nedenle yörenin deprem potansiyeli ve yerel zemin koşulları göz önünde bulundurularak yeni inşa edilecek binaların yapımında mevcut riskler göz önünde bulundurulmalı veya yapım yeri olarak deprem duyarlılı̆̆ daha düşük sahalar seçilmelidir. Özellikle yapı ile ilgili yönetmeliklere yapım ve kontrol aşamasında hassasiyetle uyulmalı ve gerekli görülmesi halinde zemin iyileştirmesi yapılmalıdır.

\section{$\underline{\text { Anahtar Sözcükler }}$}

Yerel Zemin Koşulları, Deprem Duyarlılık Analizi, CBS (Coğrafi Bilgi Sistemleri), Frekans Oranı Yöntemi, Erzincan

\section{Impact of Local Soil Conditions on Earthquake Sensitivity in Erzincan City}

\begin{abstract}
In recent years, uncontrolled growth of cities as a result of rapid population rise has caused people to go towards-inappropriate areas in terms of local soil conditions. At the same time, this situation, which increased the depression-sensitive areas in urban centers compared to the old ones, also caused the earthquakes to acquire the features of urban earthquakes. Thus, earthquake sensitivity studies based on local ground conditions have become a necessity for contemporary cities. Employing GIS (Geographic Information Systems) techniques, the present study aims to analyze the effect of the local soil conditions in Erzincan city on earthquake sensitivity through the frequency ratio method. Local soil conditions in the area where the city was established lead to a strong sense of earthquake effect. The study explores the distribution of earthquake sensitivity based on the local soil conditions in the urban area as well as its possible effects on the population. The results of this study show that Erzincan city, where 95,596 (2015) people live, has high earthquake sensitivity. The most sensitive districts to earthquake are Atatürk, Inönü, Karaağaç, Kızllay, and Yenimahalle. The damage that may result from local soil conditions in a possible instant of earthquake will be less in the areas surrounding the city where earthquake sensitivity is moderate. For this reason, considering the earthquake potential and local soil conditions, the existing risks should be taken into consideration in the construction of new buildings, or sites with a lower earthquake sensitivity should be chosen for construction. Especially, the regulations related to the building should be followed carefully in the construction and control stage and the ground improvement should be done if necessary.
\end{abstract}

Keywords

Local Soil Conditions, Earthquake Sensitivity Analysis, GIS (Geographic Information Systems), Frequency Ratio Method, Erzincan

\section{Giriş}

Son yüzyılda dünya nüfusunda yaşanan artış, kentlerin önemli birer çekim merkezi konumu kazanmasına yol açmıştır. Günümüzde dünya nüfusunun yaklaşık yarısı kentlerde yaşamaktadır. Hatta 2030 yılına kadar dünya nüfusunun \% 60 'tan fazlasının kentlerde yaşayacağı tahmin edilmektedir (Özşahin 2015). Ancak, bu durum doğal afetlere karşı çok daha fazla kırılgan bir yapıya sahip olan kentler bakımından yaşanacak risklerin büyümesine ve tam olarak kestirilememesine neden olmaktadır (Gerçek ve Güven 2016). 
Toplumları tedirgin eden, can veya mal kayıplarına neden olan ve önceden tahmin edilemeyen doğal afetlerden birisi olan depremler, hızlı kentleşmeyle birlikte kentlerin yerel zemin koşulları bakımından depreme karşı duyarlı alanlara doğru yönelmeleri sonucunda, kentsel alanlarda daha fazla etkili olmaya başlamışlardır. Maddi ve manevi kayıpların eski depremlere oranla daha fazla artmasına neden olan bu durum, yaşanan depremlerin de kent depremi olmasına yol açmıştır (Wu vd. 2014). Dolayısıyla günümüz kentlerinde yerel zemin koşullarına dayalı deprem duyarlılık çalışmalarının yapılması zorunluluk haline gelmiştir (Stein vd. 2012). Zira bu tür çalışmalar, deprem ve onunla ilgili tehlikelerin değerlendirilmesi, ortaya çıkacak sorunların çözümü için gerekli önlemlerin alınması ve uygun yer seçimi için önemli birer karar verme aracı olarak görülmektedir (McGuire 2001). Böylece yerel zemin koşullarını açıklayan parametrelerin duyarlılık analizleri sonucunda elde edilen verilerin birleştirilerek aralarındaki ilişkinin anlaşılması daha sağlıklı bir şekilde yapılmaktadır. Bütün bu işlemlerin gerçekleştirilebilmesi için elde edilen verilerin, coğrafi koordinatlarla ilişkilendirilmesi, istatistiksel veya matematiksel yöntemlerle analiz edilmesi ve görsel olarak sunumlarının yapılmasına ihtiyaç vardır (Özşahin 2014). Bu amaç için kullanılan en iyi araçlardan birisi CBS (Coğrafi Bilgi Sistemi) teknikleridir (Anbazhagan 2013).

Farklı sayıdaki değişkenler arasındaki ilişkilerin incelenmesinde ve analiz edilmesinde son yıllarda kullanılan en yaygın tekniklerden biri olan CBS sayesinde deprem duyarlılığ analiz edilip, sorunlu alanlar tespit edilebilir (Gutierrez 2005). Bu bakımdan gerek uluslararası gerek ulusal literatürde CBS tekniklerinden faydalanılarak yerel zemin koşullarına dayalı deprem duyarlılık çalışmalarının yapılması ivme kazanmıştır. Bu tür çalışmalar, doğru yer seçimi ve arazi planlamaları için önem taşır (Özşahin ve Kaymaz 2015). Zira Türkiye'de yaşanan deprem olaylarında can ve mal kaybı çok önemli rakamlara ulaşmıştır. Deprem sonucu yaşanan olumsuzluklar ise nüfus yoğunluğu, yanlış arazi kullanımı ve plansızlık sonucu ortaya çıkan yapılaşmadan kaynaklanmaktadır (Özşahin ve Değerliyurt 2013).

CBS destekli deprem duyarlılık haritalarının üretilmesinde değişik türden deterministik (tanımsal) ve probabilistik (olasılıksal) yöntemler tercih edilmektedir. Deterministik yöntemlere kıyasla probabilistik yöntemler, çeşitli türden veriler arasındaki ilişkinin en uygun şekilde değerlendirilerek daha fazla verimin elde edilmesine müsaade etmektedir (Erdik vd. 2011). Bu amaçla yararlanılan probabilistik yöntemlerden birisi de frekans oranıdır (Dar ve Dubey 2015). Daha rahat tarihsel envanter verisi sağlandığı için çoğunlukla heyelan duyarlılık haritalarının hazırlanmasında kullanılan frekans oranı yöntemi, diğer doğal afetlere yönelik çalışmalarda veri sıkıntısından dolayı genellikle göz ardı edilmiştir (Yalcin vd. 2011; Rozos vd. 2013; Regmi vd. 2014; Cao vd. 2016). Bu durum bazı doğal afetler hakkında elde edilen sağlıklı mekânsal verilerin oldukça yetersiz veya eksik kalmasından kaynaklanmış olmalıdır. Ancak son yıllarda doğru ve düzgün mekânsal veri toplanmasına paralel olarak frekans oranı yöntemine dayalı değişik doğal afetlere yönelik duyarlılık çalışmaları yapılmaya başlanmıştır (Suarez vd. 2014).

İki değişkenli istatistiksel yöntemlerden biri olan frekans oranı yöntemi, afete yol açan faktörler ile geçmişte yaşanmış afetler arasındaki mekânsal ilişkisinin incelenmesinde çok iyi performans göstermektedir (Pham vd. 2015). Bu performans sayesinde birçok yönteme göre çok yüksek başarı ve tahmin oranı verdiği için, nispeten daha güvenilir sonuçlara ulaşılmasını sağlamaktadır (Pradhan ve Lee 2010; Abul Hasanat vd. 2010). Diğer yandan bu yöntemde veri kümesinin büyük olduğu durumlarda bile veri dönüşümüne veya sınırlandırılmış değerlere ihtiyaç duyulmadığ için basit bir şekilde uygulandığı rapor edilmiştir (Park vd. 2013). Ayrıca ilgili yöntem sayesinde uygulamaya ve planlamaya yönelik daha akılcı ve bilimsel sonuçlar elde edilmektedir (Vakhshoori ve Zare 2016).

CBS tekniklerinin bir araç olarak kullanıldığı bu çalışmada, Erzincan kentinin yerel zemin koşullarının deprem duyarlılığına etkisinin frekans oranı yöntemiyle analiz edilmesi amaçlanmıştır. Zira bu kent, Türkiye'de meydana gelmiş en büyük depremlerden birisinin yaşandığı yerdir (Akpınar vd. 2016). Kentin kurulduğu alanın yerel zemin koşulları, deprem etkisinin kuvvetli bir şekilde hissedilmesine yol açmaktadır (Aslan 2015). Nitekim deprem dalgalarının geçtikleri zeminlerin özelliklerine göre değişime uğradıkları ve bu nedenle yerel zemin koşullarının yapılarda hasar oluşturacak şekilde çeşitli etkilerle kendini gösterdiği bildirilmiştir (Korkmaz 2006). Gerçekten de yakın geçmişte meydana gelen 17 Ağustos 1999 Gölcük, 1 Mayıs 2003 Bingöl ve 23 Ekim 2011 Van depremlerinde görüldüğü üzere deprem sonucunda meydana gelen can ve mal kayıplarının fazla olmasının asıl nedeni, zemin özellikleri ile deprem etkisi arasındaki ilişkiyi dikkate alan hazırlıkların yapılmamasıdır.

Çalışma kapsamında 95.596 kişinin yaşadığı (URL-1 2018) Erzincan kentinin yerel zemin koşullarına bağlı olarak deprem duyarlılığının dağılışı ve bunun nüfusa yönelik olası etkileri irdelenmiştir. Ayrıca bu çalışma sayesinde sismotektonik bakımdan hassas bir bölgede yer alan Erzincan kentinde yerel zemin koşulları ve deprem duyarlılık konusunu ele alan diğer araştırma ve planlamalara yol gösterilmesi amaçlanmıştır. Çalışmanın en orijinal yanı da deprem duyarlılığı konusunda dünyada çok az, Türkiye'de ise herhangi bir alanda uygulanmamış farklı bir yöntemin Erzincan kenti örneğinde incelenmesidir.

\section{Inceleme Alanı}

İnceleme alanı, Doğu Anadolu Bölgesi’nin Yukarı Fırat Bölümü’nde kalan Erzincan kenti ve yakın çevresidir. Erzincan kenti, kendi adıyla anılan ovanın tabanında bulunmakta olup, 2788.5 ha'lık bir sahada yayılım göstermektedir (Şekil 1). Türkiye'nin jeolojik açıdan en karmaşık yörelerinden KAF (Kuzey Anadolu Fayı) zonu üzerinde konumlanan inceleme alanı, sismotektonik bakımdan çok aktif bir düğüm noktasında kalır (Tüysüz 1993). 
Dolayısıyla kent alanı, KAF, Kuzeydoğu Anadolu Fayı ve Ovacık Fayı ile bunlara bağlı tali fay hatlarıyla kuşatılmıştır (Şekil 1). Halen aktif olan bu fayların hareket hızları ise sırasıyla $1 \mathrm{~cm} / \mathrm{y} 11,0.2 \mathrm{~cm} / \mathrm{y} 1 \mathrm{l}$ ve $0.15 \mathrm{~cm} / \mathrm{y}$ 1l olarak ölçülmüştür (Barka 1993; Eyidoğan 1993).

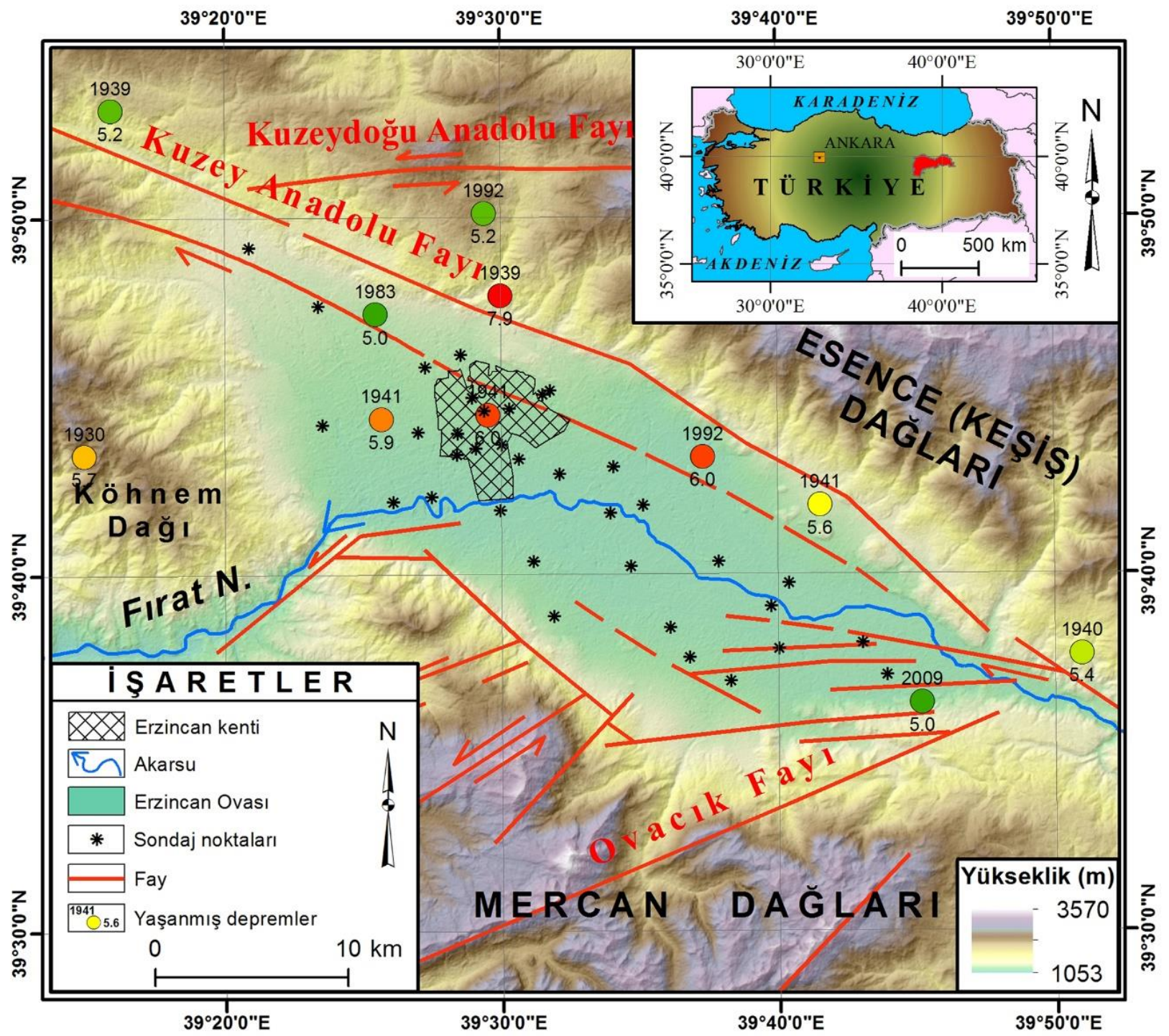

Şekil 1: Inceleme alanının konumu ve depremsellik haritası (Tüysüz 1993'den faydalanılarak)

İnceleme alanı ve yakın çevresindeki temel arazi, kuzeydoğuda yer alan dağlık alan civarında izlenen Triyas yaşlı ofiyolitik melanja ait birimlerle temsil edilmektedir (Şekil 2a). Serpantinleşmiş bu formasyonların arasında yer yer Pliyokuvaterner yaşlı konglomeralara da rastlanmaktadır (Öztaş 1993). Dağlık sahanın etek kısımlarında bazı alanlardaki izlenen yamaç molozları ve Erzincan Ovası'nın tabanındaki kil, silt, kum ve çakıl türevinden alüvyal çökeller ise Kuvaterner'e ait en genç oluşuklardır (Şekil 2a). Genellikle iri malzemelerden oluşan bu çökeller, yeraltısuyu oluşumuna ve depolanmasına katkı sağlamaktadırlar. Ovadaki alüvyonların tabanında ise genellikle ofiyolitik melanja ait birimlerin yer aldığı tahmin edilmektedir (Ada ve Ergin 1993).

Faylarla biçimlendirilmiş tektonik bir depresyonun tabanında yer alan inceleme alanı, hemen kuzeydoğusundan Esence (Keşiş) Dağları tarafından sınırlandırılmıştır (Şekil 2b). Bu dağlardan kaynaklarını alan akarsuların ova tabanına ulaştıkları kesimlerde birikinti konileri şekillenmiştir (Akkan 1964). Erzincan kenti ise ilgili koniler ile Fırat nehri arasında gelişim göstermiştir (Şekil 2b). Kentin Fırat nehrine doğru olan kesimleri, topoğrafik anlamda ovanın en alçak kısmını oluşturmakta olup, yeraltısuyu seviyesinin yüksek olduğu mekânlara karşılık gelmektedir. Bununla birlikte ortalama 1200 m yükseltiye sahip ova tabanı ile kuzeydeki dağlar arasında 2350 m'ye varan yükselti farkları mevcuttur (Hayli 2012). 

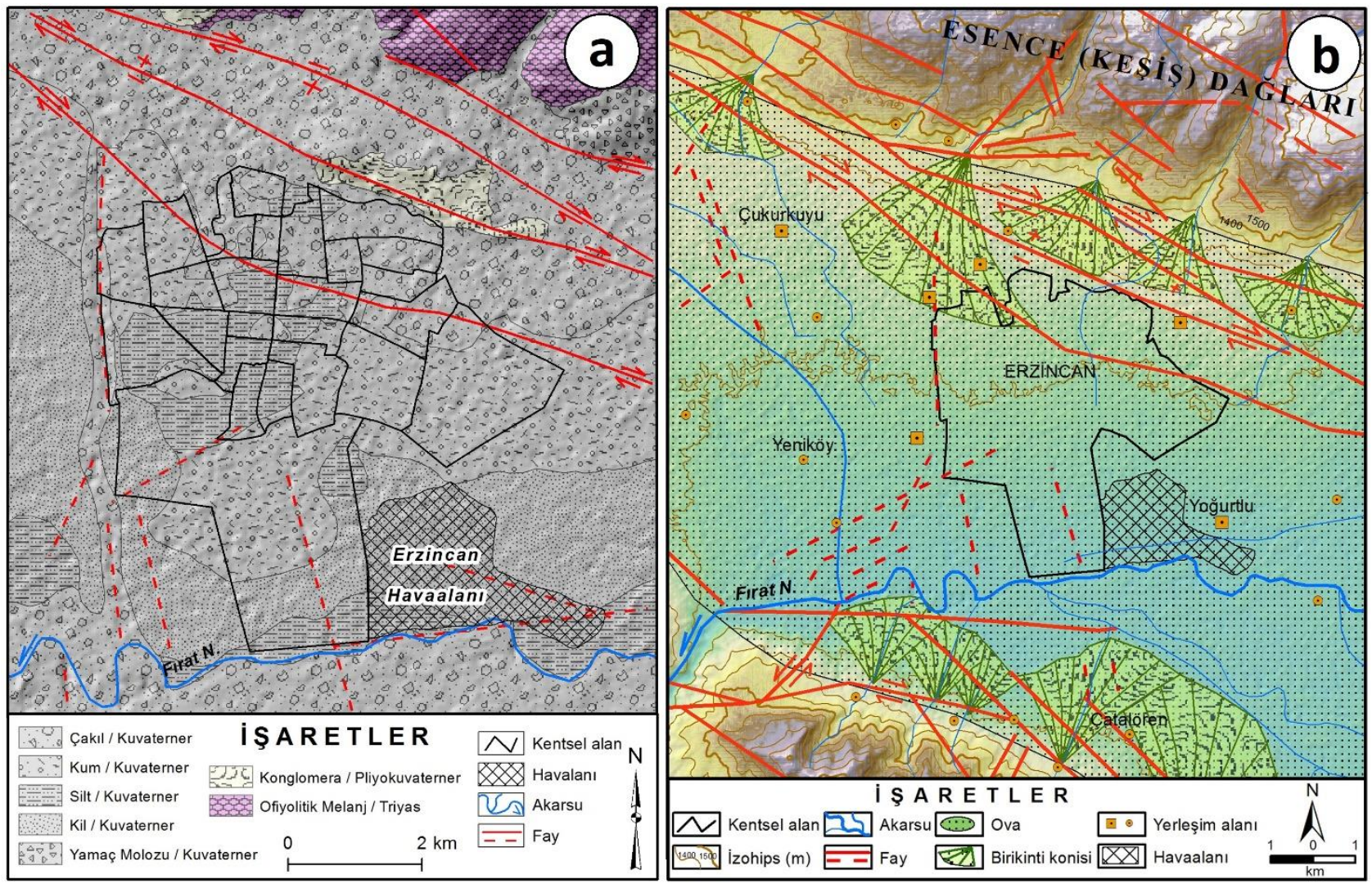

Şekil 2: Inceleme alanının jeolojik ve morfotektonik haritaları a) jeoloji haritası (Öztaş 1993’ten yeniden çizilerek), b) inceleme alanının genel morfotektonik haritası (Tüysüz 1993’ten faydalanılarak çizilmiştir)

İnceleme alanı ve yakın çevresinin tamamı, birinci derece deprem bölgeleri sınırları dâhilinde kalmaktadır. Bu bakımdan sahada hem tarihsel hem de aletsel dönemde birçok deprem yaşanmıştır (Tablo 1). Tarihsel dönemde 17 yıkıcı depremin meydana geldiği bu sahada, çok büyük oranda can ve mal kayıpları gerçekleşmiştir (Tablo 1). Hatta Erzincan kenti tarihsel dönemde gerek can kaybı, gerekse ağır hasarlı bina açısından Türkiye'de meydana gelmiş en büyük depremlerden birisinin yaşandığı mekânlardan birisidir (Tablo 1).

Tablo 1: Inceleme alanında tarihsel ve aletsel dönemde oluşmuş önemli depremler (Aslan 2015)

\begin{tabular}{|c|l|c|c|c|c|l|}
\hline Tarih & Enlem (K) & Boylam (D) & Magnitüd (Ms) & Şiddet & Can Kaybı & Hasarlı Bina \\
\hline 967 & $39^{\circ} 80^{\prime}$ & $39^{\circ} 50^{\prime}$ & - & VIII & 1.200 & Çok sayıda \\
\hline 1011 & $39^{\circ} 75^{\prime}$ & $39^{\circ} 50^{\prime}$ & - & VIII & Çok ölü & Kent yıkılmış \\
\hline 1045 & $39^{\circ} 75^{\prime}$ & $39^{\circ} 50^{\prime}$ & - & IX & 12.000 & Çok sayıda \\
\hline 1161 & $39^{\circ} 75^{\prime}$ & $39^{\circ} 50^{\prime}$ & - & VII & Çok ölü & Çok sayıda \\
\hline 1168 & $39^{\circ} 75^{\prime}$ & $39^{\circ} 50^{\prime}$ & - & VIII & Çok ölü & Kent yıkılmış \\
\hline 1236 & $39^{\circ} 75^{\prime}$ & $39^{\circ} 50^{\prime}$ & - & VII & Çok ölü & Çok sayıda \\
\hline 1254 & $39^{\circ} 75^{\prime}$ & $39^{\circ} 50^{\prime}$ & - & VIII & 16.000 & Çok sayıda \\
\hline 1268 & $39^{\circ} 75^{\prime}$ & $40^{\circ} 40^{\prime}$ & - & IX & 15.000 & Çok sayıda \\
\hline 1281 & $39^{\circ} 75^{\prime}$ & $39^{\circ} 50^{\prime}$ & - & VI & Çok ölü & Çok sayıda \\
\hline 1287 & $39^{\circ} 75^{\prime}$ & $39^{\circ} 50^{\prime}$ & - & VIII & Çok ölü & Çok sayıda \\
\hline 1289 & $39^{\circ} 75^{\prime}$ & $39^{\circ} 50^{\prime}$ & - & VII & Çok ölü & Çok sayıda \\
\hline 1290 & $39^{\circ} 75^{\prime}$ & $39^{\circ} 50^{\prime}$ & - & VI & Çok ölü & Çok sayıda \\
\hline 1308 & $39^{\circ} 75^{\prime}$ & $39^{\circ} 50^{\prime}$ & - & VII & Çok ölü & Çok sayıda \\
\hline 1345 & $39^{\circ} 75^{\prime}$ & $39^{\circ} 50^{\prime}$ & - & VI & Çok ölü & Çok sayıda \\
\hline 1356 & $39^{\circ} 75^{\prime}$ & $39^{\circ} 50^{\prime}$ & - & VI & Çok ölü & Çok sayıda \\
\hline 1366 & $39^{\circ} 75^{\prime}$ & $39^{\circ} 50^{\prime}$ & - & VI & Çok ölü & Çok sayıda \\
\hline 1374 & $39^{\circ} 75^{\prime}$ & $39^{\circ} 50^{\prime}$ & - & VIII & Çok ölü & Kent yıkılmış \\
\hline 1422 & $39^{\circ} 75^{\prime}$ & $39^{\circ} 50^{\prime}$ & - & VIII & Çok ölü & Çok sayıda \\
\hline 1433 & $39^{\circ} 75^{\prime}$ & $39^{\circ} 50^{\prime}$ & - & VI & Çok ölü & Çok sayıda \\
\hline
\end{tabular}


Tablo 1'in devamı

\begin{tabular}{|c|c|c|c|c|c|c|}
\hline Tarih & Enlem (K) & Boylam (D) & Magnitüd (Ms) & Siddet & Can Kaybı & Hasarlı Bina \\
\hline 1456 & $39^{\circ} 75^{\prime}$ & $39^{\circ} 50^{\prime}$ & - & VIII & Çok ölü & Kent yıkılmış \\
\hline 1458 & $39^{\circ} 75^{\prime}$ & $39^{\circ} 50^{\prime}$ & - & $\bar{X}$ & Çok ölü & Çok sayıda \\
\hline 1482 & $39^{\circ} 75^{\prime}$ & $39^{\circ} 50^{\prime}$ & - & IX-X & Çok ölü & Çok sayıda \\
\hline 1543 & $39^{\circ} 75^{\prime}$ & $39^{\circ} 50^{\prime}$ & - & VII & Çok ölü & Kent yıkılmış \\
\hline 1576 & $39^{\circ} 75^{\prime}$ & $39^{\circ} 50^{\prime}$ & - & VII & 1.500 & Çok sayıda \\
\hline 1579 & $39^{\circ} 75^{\prime}$ & $39^{\circ} 50^{\prime}$ & - & VIII & Çok ölü & Çok sayıda \\
\hline 1584 & $39^{\circ} 75^{\prime}$ & $39^{\circ} 50^{\prime}$ & - & IX & Çok ölü & Çok sayıda \\
\hline 1667 & $39^{\circ} 75^{\prime}$ & $39^{\circ} 50^{\prime}$ & - & VIII & Çok ölü & Çok sayıda \\
\hline 1784 & $39^{\circ} 75^{\prime}$ & $39^{\circ} 50^{\prime}$ & - & VIII & Çok ölü & Çok sayıda \\
\hline 1787 & $39^{\circ} 75^{\prime}$ & $39^{\circ} 50^{\prime}$ & - & VIII & Çok ölü & Çok sayıda \\
\hline 1888 & $39^{\circ} 75^{\prime}$ & $39^{\circ} 50^{\prime}$ & - & VII & Çok ölü & Kent yıkılmış \\
\hline 1939 & $39^{\circ} 75^{\prime}$ & $39^{\circ} 50^{\prime}$ & 7.9 & $\mathrm{X}$ & 32.968 & 116.720 \\
\hline 1941 & $39^{\circ} 75^{\prime}$ & $39^{\circ} 50^{\prime}$ & 5.9 & & 15 & Hafif hasar \\
\hline 1949 & $39^{\circ} 75^{\prime}$ & $39^{\circ} 50^{\prime}$ & 6.7 & & 450 & Hafif hasar \\
\hline 1978 & $39^{\circ} 75^{\prime}$ & $39^{\circ} 50^{\prime}$ & 4.7 & & & Hafif hasar \\
\hline 1980 & $39^{\circ} 75^{\prime}$ & $39^{\circ} 50^{\prime}$ & 4.4 & & & Hafif hasar \\
\hline 1983 & $39^{\circ} 75^{\prime}$ & $39^{\circ} 50^{\prime}$ & 4.1 & & & Hafif hasar \\
\hline 1992 & $39^{\circ} 75^{\prime}$ & $39^{\circ} 50^{\prime}$ & 6.8 & VIII & 653 & 8.057 \\
\hline 2009 & $39^{\circ} 75^{\prime}$ & $39^{\circ} 50^{\prime}$ & 5.0 & & & Hafif hasar \\
\hline
\end{tabular}

Aletsel dönem boyunca deprem etkinliğinin devam ettiği inceleme alanında, 1900-2016 yılları arasında 14 büyük deprem meydana gelmiştir. Büyüklüğü 5 ve üzerinde olan bu depremlerden en şiddetlileri, 1939 (M: 7.9) ve 1992 (M: 6.8) yıllarında gerçekleşmiştir (Tablo 1). Nitekim 26 Aralık 1939 tarihinde yaşanan depremde 32.968 kişi hayatını kaybetmiş, yaklaşık 100.000 kişi yaralanmış ve 116.720 bina yıkılmıştır. Aynı sahada yaklaşık yarım asır sonra tekrar 6.8 büyüklüğünde bir deprem olmuștur. 13 Mart 1992 tarihinde gerçekleşen bu deprem sonucunda, 653 kişi hayatını kaybetmiş ve 8057 bina hasar görmüş veya yıkılmıştır (Kurtuluş 1993). Erzincan ve yakın çevresinde tarihsel ve aletsel dönemde meydana gelmiş büyük depremler, gelecekte benzer afetlerin olabileceğine işaret etmektedir. Deprem gerçeğini çok net bir şekilde yansıtan bu durum, Erzincan kentinde ivedilikle çeşitli önlemlerin alınmasını zorunlu kılmaktadır. Bu önlemlerin başında ise arazi kullanım ve imar planlarının söz konusu deprem gerçeğine uygun olarak yapılması gelmektedir (Şengezer 1993).

\section{Materyal ve Yöntem}

Herhangi bir tehlikenin gerçekleşmesi halinde, canlıların ve insan tarafından oluşturulan yaşam ortamının maruz kalacağı zarar veya kayıplara olan hassasiyet şeklinde tanımlanan duyarlılık (hassasiyet veya zarar görebilirlik), aynı zamanda bir yerin veya sistemin kendi içinde tehlike oluşturan bir duruma karşı gösterdiği zayıflıktır (Değerliyurt 2015). Bu zayıflık, zarar verme potansiyeline sahip tüm olay ve olgular şeklinde açıklanan tehlike ile belirli bir tehlikenin yaşanması halinde insanlara ve çevreye zarar veya hasar verebilme durumuna bağlı ortaya çıkabilecek kayıp olasılığı biçiminde açıklanan risk kavramlarına gidilen yolun ilk basamağını oluşturur (Ösna 2013). Bu bakımdan duyarlılık analizleri, günümüz dünyasında karşılaşan mekânsal sorunların giderilmesi, belirsizliklerin tanımlanması ve karar verme modellerinin uygulanmasında ve etkin bir biçimde kullanılmasında sıklıkla kullanılan bir araçtır (Gökkaya 2014). Nitekim çeşitli türden afetler için yapılan duyarlılık analizleri sayesinde duyarlı alanlar belirlenip, buna göre çeşitli önlemler alınabilmektedir.

Deprem duyarlılık analizlerinde ise temel amaç, tehlikeli alanların tespit edilerek deprem etkilerinin azaltılmasını sağlamaktır. Erzincan kentinin deprem ve yerel zemin koşulları arasındaki ilişkinin incelendiği bu deprem duyarlılık çalışması, beş farklı temel yerel zemin parametresi (litoloji, fay hatlarına uzaklık, yeraltısuyu seviyesi, zemin kayma hızı ve büyütme oranı) üzerinden gerçekleştirilen CBS destekli analize göre yapılmıştır. Zira deprem konusunda yapılan çalışmalar gün geçtikçe kalite ve kapsam bakımından artmaktadır. Ayrıca, bu tarz çalışmalar son yıllarda CBS destekli yöntemlerle etkin bir şekilde desteklenmektedir.

Çalışmada gerçekleştirilen analize ait veri seti, farklı kurum ve kuruluşlar tarafından hazırlanmış değişik tematik haritalardan faydalanılarak oluşturulmuştur (Tablo 2). Temel harita verileri, büyük ölçekli (Ölçek: 1/25.000) topoğrafya haritaları (Harita Genel Komutanlığı 2015) ve kent planından (Erzincan Belediyesi 2016) yararlanılarak aktarılmıştır. Deprem hasar envanteri ve jeolojik özelliklere ait bazı bilgiler yapılmış eserlerden derlenmiştir. Litoloji ve fay hatlarına mesafe ile ilgili bilgiler ise Türkiye jeoloji veri bankası 1/25.000 ölçekli sayısallaştırılmış jeoloji haritaları (MTA 2016) sisteminde bulunan ilgili paftalardan yararlanmak suretiyle temin edilmiştir. 
Yeraltısuyu seviyesi, zemin kayma hızı ve büyütme oranı faktörlerine ait haritalar da, Erzincan kenti ve yakın çevresinde değişik kesimlerden alınan 43 adet sondaj verisine (Dönmezçelik 2015), nüfus dağılım haritası ise güncel mahalle nüfuslarına (URL-1 2018) dayalı bir şekilde oluşturulmuştur. Hem sondaj verileri hem de mahalle nüfuslarının mekânsal dağılışı, CBS ortamında IDW (Ters Mesafe Ağırlıklı Enterpolasyon) jeoistatiksel analiz tekniğiyle yapılmıştır. Çalışma kapsamında üretilen tematik haritalar elde edilen veriler ve proje amacına bağlı olarak 1:25000 ölçeğinde hazırlanmıştır. Çünkü kentsel alanlarda duyarlılık haritalarının doğru hazırlanması için, bu detayda veya daha büyük bir ölçeğin kullanılması oldukça uygundur (Özşahin ve Değerliyurt 2013).

Tablo 2: Çalışmada kullanılan veriler, türleri ve tedarik edildiği kaynaklar

\begin{tabular}{|c|c|c|}
\hline Veri türü & Veri kaynağı & Kullanım alanı \\
\hline Topoğrafya Haritaları & Harita Genel Komutanlığ 2015 & \multirow{2}{*}{$\begin{array}{l}\text { Temel harita verileri (Akarsu, yol, } \\
\text { mahalle sinırları vs.) }\end{array}$} \\
\hline Kent Planı & Erzincan Belediyesi 2016 & \\
\hline Yap1 Hasarları Dağılımı Haritas1 & Öztaş 1993 & Deprem hasar envanteri \\
\hline Jeoloji Haritası & Öztaş 1993; MTA 2016 & $\begin{array}{l}\text { Litoloji } \\
\text { Fay Hatlarına mesafe }\end{array}$ \\
\hline Yeraltısu seviyesi değerleri & \multirow{3}{*}{ Dönmezçelik 2015} & Yeraltı su seviyesi \\
\hline $\begin{array}{l}\text { Zemin kayma hızı (Vs30) } \\
\text { değerleri }\end{array}$ & & Zemin kayma hızı \\
\hline Zemin Büyütme değerleri & & Zemin Büyütme oranı \\
\hline Mahalle Nüfusları (2015) & URL-1 2018 & Nüfus Dağılım Haritası \\
\hline
\end{tabular}

Çalışmada yöntem olarak CBS destekli frekans oranı yöntemi uygulanmıştır. Bir olayın gerçekleşme ihtimalinin gerçekleşmeme ihtimaline oranı şeklinde tanımlanan bu yöntem (Akıncı vd. 2011), geçmişte yaşanmış bir depremin yol açtığı hasarın deprem duyarlılığını etkileyen faktörlerle ilişkisinin ayrı ayrı ortaya konması esasına dayanmaktadır. Böylece geçmiş deprem hasarları ve deprem duyarlılığı arasındaki yakın ilişkiden yola çıkarak gelecekte yaşanabilecek bir depremin mekânsal hasarın dağılışına etkisi tahmin edilebilmektedir. $\mathrm{Bu}$ yöntemin avantajı, deprem duyarlılık çalışmalarında kullanılan diğer yöntemlere kıyasla daha anlaşılır ve uygulanabilir olmasıdır. Zira konu hakkında daha önce uygulanmış diğer birçok yöntemde genellikle uzman kişiler puanlama yaparken, bu yöntemde doğrudan hasara göre puanlama gerçekleştirilmektedir. Dolayısıyla bu durum daha objektif değerlendirmeleri mümkün kılmaktadır. Buna karşın yöntemin en önemli dezavantajı ise deprem hasarlarının dağılışını gösteren deprem hasar envanteri haritalarına ihtiyaç duyulmasıdır. Daha çok yapı hasar oranları sunulan bu tür haritaların çizimi genellikle zaman, imkân ve emek ölçüsü bakımından oldukça zordur. Ayrıca bu tür haritalarda genellikle mevcut yapıların hangi yönetmenliklere göre inşa edildiği veya yapı malzemesi/kalitesi/yaşı hakkında doğrudan bilgi bulunmamaktadır.

Bu çalışmada kullanılmış frekans oranı yöntemi, ulaşılabilen en sağlıklı veri olduğu düşünüldüğü için "13 Mart 1992 Yapı Hasarları Dağılımı Haritası” (Öztaş 1993) dikkate alınarak düzenlenen Deprem Hasar Envanteri kullanılarak tatbik edilmiştir. Bu envanterde yapı hasar oranları; az, orta ve ağır hasarlı olmak üzere üç farklı kategoride sunulmuştur (Şekil 3). O dönemde $5.818 .832 \mathrm{~m}^{2}$ 'lik bir alan üzerinde yapılan bu ayrıma göre sahada, büyükten küçüğe doğru sırasıyla az (\% 60), orta (\% 25) ve ağır (\% 15) hasarlı yapı oranları hâkimdir. Ancak ilgili haritada mevcut yapılar hakkında (yap1 malzemesi, kalitesi, yaşı vs.) doğrudan herhangi bir bilgi mevcut değildir. Ayrıca yıllara göre kent sınırında izlenen önemli değişiklikler ve yürürlükte olan deprem yapı yönetmeliğinin birbirinden farklılık göstermesi deprem duyarlılığını etkilese bile yapı özellikleriyle alakalı herhangi bir veri olmadığı için bu ayrıntı göz ardı edilmiştir. Dolayısıyla çalışmada sahadaki yapı hasar oranlarının doğrudan kullanılması ve ilgili oranlara göre ortalama hasar dağılımında standart bir değerin belirlenmesi mümkün olmamıştır. Bu sebeple bilimsel yönteme daha uygun bir yol olduğu düşünüldüğü için çalışmada elde edilmiş bütün yapı hasarları gruplandırmadan doğrudan hasarlı yapı olarak kabul edilmiş ve bu genel durum çerçevesinde duyarlılık sonrası ortalama hasar dağılım oranları belirlenmiştir.

Daha sonra bu envanterdeki hasar alanı yüzdesi (B) yerel zemin parametre sınıflarının toplam alan (A) değerine bölünerek frekans oranı (B/A) tespit edilmiştir (Tablo 3).

Takip eden aşamada frekans oranları saptanan parametrelerin ağırlık değerleri, aşağıdaki eşitlik yardımıyla hesaplanmıştır (Süzen 2002);

$W=(1000 *(B / A))-(1000 *(\Sigma B / \Sigma A))$

Bu eşitlikteki W; parametre ağırlık değerini; B; parametre sınıfındaki hasarlı alanın piksel sayısını ve A ise parametre sınıfındaki toplam piksel sayısını ifade etmektedir. Parametre haritalarına ilişkin ağırlık değerlerinin pozitif çıkması ilgili parametrenin deprem oluşumunda etkisinin daha fazla, negatif çıkması ise etkisinin göreceli olarak daha az olduğunu göstermektedir (Dağ ve Bulut 2012). Çalışmanın analiz kısmı, ağırlık değerleri belirlenmiş faktör haritaların CBS ortamında $10 \mathrm{~m}$ çözünürlüğündeki grid formatta raster haritalara dönüştürülüp, birleştirilmesi sonucunda tamamlanmıştır. Bütün bu işlemlerin ardından, gelecekte yaşanabilecek depremlere karşı duyarlı alanların gösterildiği ve herhangi bir alanın depreme karşı eğilimini ifade eden deprem duyarlılık haritası oluşturulmuştur. 
Elde edilen duyarlılık sonuçlarının derecelendirilmesi ise Liu vd (2012) tarafından kullanılmış olan dört seviyeye göre düşük, orta, yüksek ve çok yüksek olmak üzere sınıflandırılmıştır.

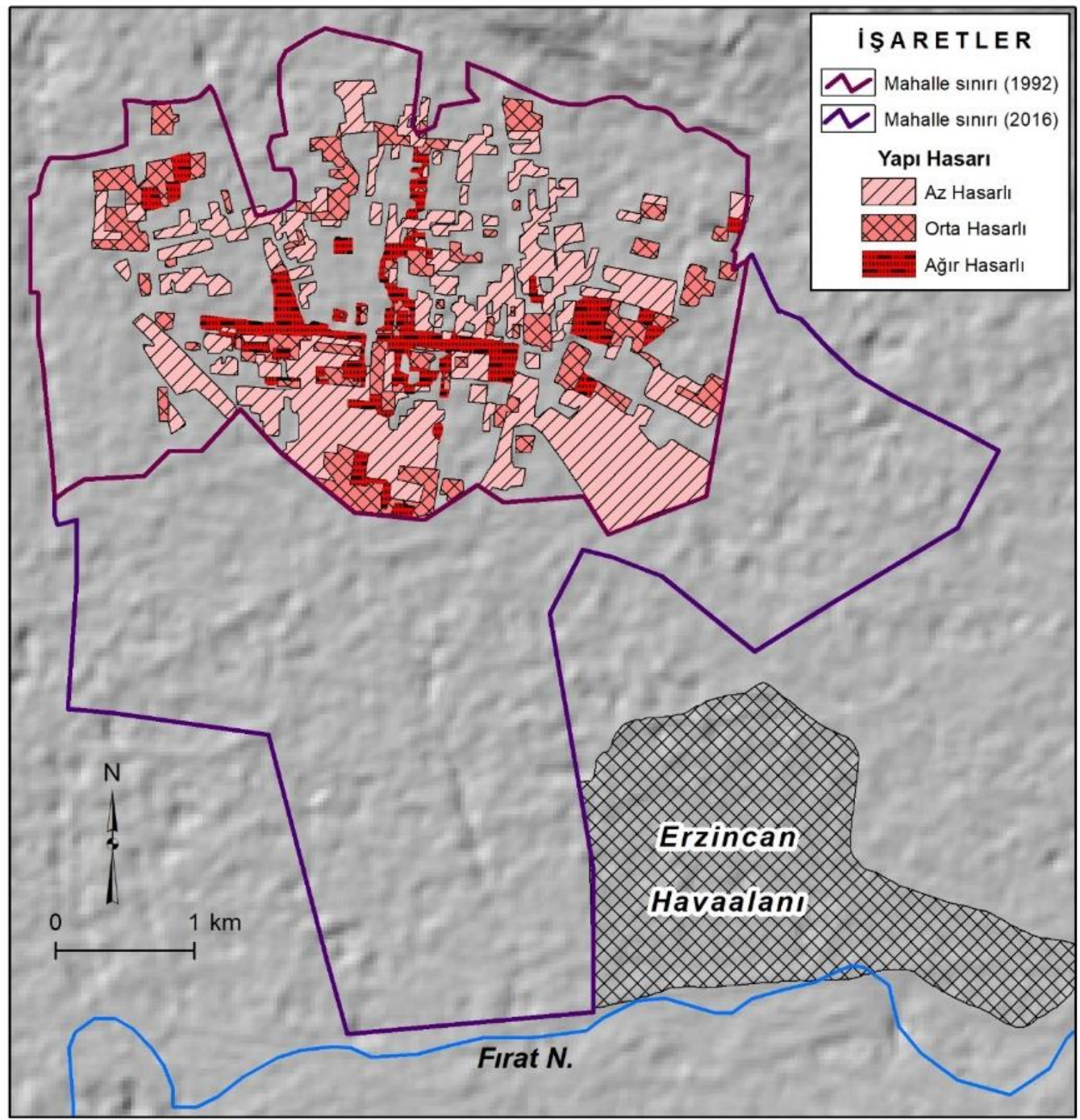

Şekil 3: Inceleme alanının 13 Mart 1992 Yapı Hasarları Dağııımı haritası (Öztaş 1993’ten yeniden çizilerek)

Tablo 3: Çalışmada kullanılan parametre sınıflarııın alanı (ha) ve ağırlık değerleri

\begin{tabular}{|c|c|c|c|c|}
\hline \multicolumn{2}{|c|}{ Yerel zemin parametre sınıfları } & Toplam Alan (A) & Hasar Alanı Yüzdesi (B) & Frekans Oranı (B/A) \\
\hline \multirow{5}{*}{ Litoloji } & Çakıl & 3224.39 & 152.95 & 0.05 \\
\hline & Kum & 2077.16 & 206.35 & 0.10 \\
\hline & Silt & 973.62 & 222.57 & 0.23 \\
\hline & Kil & 1823.16 & - & - \\
\hline & Konglomera & 182.67 & - & - \\
\hline \multirow{5}{*}{ Fay hatlarına mesafe } & $0-15$ & 71.40 & $\overline{5.80}$ & 0.08 \\
\hline & $15.01-30$ & 71.40 & 5.80 & 0.08 \\
\hline & $30.01-45$ & 71.40 & 5.80 & 0.08 \\
\hline & $45.01-60$ & 71.40 & 5.80 & 0.08 \\
\hline & $60.01->$ & 7995.40 & 558.67 & 0.07 \\
\hline
\end{tabular}


Tablo 3'ün devamı

\begin{tabular}{|c|c|c|c|c|}
\hline \multicolumn{2}{|c|}{ Yerel zemin parametre sınıfları } & Toplam Alan (A) & Hasar Alanı Yüzdesi (B) & Frekans Oranı (B/A) \\
\hline \multirow{5}{*}{ Yeraltisuyu } & $<--20.01$ & 203.95 & 117.17 & 0.57 \\
\hline & $-15.01--20$ & 626.20 & 246.92 & 0.39 \\
\hline & $-10.01--15$ & 2248.58 & 214.72 & 0.10 \\
\hline & $-5.01--10$ & 4446.40 & 3.06 & - \\
\hline & $-5->$ & 755.87 & - & - \\
\hline \multirow{5}{*}{ Zemin Kayma Hızı } & $<-350$ & 287.79 & - & - \\
\hline & $350.01-400$ & 2944.82 & 120.55 & 0.04 \\
\hline & $400.01-450$ & 4092.86 & 458.17 & 0.11 \\
\hline & $450.01-500$ & 851.90 & 3.15 & - \\
\hline & $500.01->$ & 103.63 & - & - \\
\hline \multirow{5}{*}{ Büyütme oranı } & $<-1.8$ & 1630.09 & 24.60 & 0.02 \\
\hline & $1.8-1.9$ & 3719.86 & 465.63 & 0.13 \\
\hline & $1.9-2$ & 2281.02 & 90.54 & - \\
\hline & $2-2.1$ & 562.62 & 1.10 & - \\
\hline & $2.1->$ & 87.41 & - & - \\
\hline \multicolumn{2}{|c|}{ Toplam } & 8281.00 & $\mathbf{5 8 1 . 8 7}$ & \\
\hline
\end{tabular}

\section{Bulgular}

\subsection{Deprem Duyarlılığını Etkileyen Faktörler}

Deprem duyarlılığı üzerinde çeşitli faktörler rol oynamaktadır. Bu faktörlerden birisi yerel zemin koşullarıdır. Zira herhangi bir depremin oluşturacağı etkinin boyutu, deprem vasfinın yanında yerel zemin koşullarına bağlı olarak değiş̧mektedir (Tohumcu vd. 2003; Işık ve Kutanis 2015; Işı1k vd. 2016). Bu koşullar; tektonik, litolojik, jeomorfolojik ve hidrojeolojik özelliklerin tamamının bileşkesini meydana getirmektedir (Korkmaz 2006). Bunun için inceleme alanının litoloji, fay hatlarına uzaklık, yeraltısuyu seviyesi, zemin kayma hızı ve büyütme oranı parametrelerinden oluşan yerel zemin koşulları deprem duyarlılığı açısından analiz edilmiş̧tir (Şekil 4).

Erzincan Ovası'nın tabanında bulunan Erzincan kenti, litolojik olarak çok genç ve depreme karşı dayanıksız birimler üzerinde bulunmaktadır. Kentin çok zayıf veya zayıf zeminler üzerinde yayılım göstermesi, olası bir deprem anında meydana gelecek hasarın derecesini arttıracaktır. Çünkü litolojik özellikler deprem şiddetini arttırıcı ya da azaltıcı bir etkiye sahiptir (Şen 2011).

Bu bağlamda inceleme alanında en büyük frekans oranı (0.23) silt litolojisindeki zeminlerde tespit edilmiştir (Tablo 3; Şekil 4). İlgili zeminlerin deprem açısından yüksek pozitif ağırlık değerine (158.33) sahip olması, deprem şiddetinin ve hasar derecesinin artmasına neden olacaktır (Tablo 3; Şekil 4). Diğer yandan inceleme alanında deprem etkisinin çok net hissedileceği bir diğer zemin grubu ise kumlu zeminlerdir. Nitekim pozitif ağırlık değerleri (29.08) gösteren bu zeminler nispeten yüksek frekans oranı (0.10) vermişlerdir.

Böylece inceleme alanındaki siltli ve kumlu zeminlerin depreme karşı en duyarlı litolojik birimler olduğu anlaşılmıştır (Tablo 3; Şekil 4). Zaten Erken vd. (1993) Erzincan kentinde yerel zemin koşullarına bağlı hasarın daha çok siltli ve kumlu zeminlerde arttı̆ıını bildirmişlerdir. Sahadaki diğer litolojilerde ise ağırlık değerleri negatif olduğu için deprem etkisi göreceli olarak daha az hissedilecektir.

Yerel zemin koşulları ile deprem duyarlılığı arasındaki ilişkiyi ortaya koyan diğer bir faktör ise fay hatlarına uzaklıktır. Bu sahaya yakın ve uzak çevrede gerçekleşmiş birçok depremin faylardan uzaklaştıkça duyarlılığın artacağı şeklinde bir yorumlamaya gidilemeyeceği göstermesinden dolayı bu faktörün göz ardı edilmesi ve bunun yerine, daha temsil edici bir parametre olarak yer ivme değeri kullanılması düşünülmüştür. Ancak sahaya ait yer ivme değerleri, bu çalışmada değerlendirilen zemin kayma hızı verilerinden sağlandığı için (Askan vd. 2015) duyarlılığı güçlendirmek ve tahmin oranını yükseltmek adına fay hatlarına uzaklık faktörünün kullanımı tercih edilmiştir.

Tektonik kökenli bir depresyonda yer alan inceleme alanı, KAF ve bu yöredeki segmentlerinin etkisi altında kalmaktadır. Ayrıca sahadaki alüvyal dolguların altında da birçok fay hattının bulunduğu bildirilmiştir (Özkan 1992). Bu bakımdan Erzincan kenti için fay hatlarına uzaklık faktörü oldukça önemlidir. Depreme etki eden diğer faktörlerle birlikte değerlendirildiğinde doğru çıkarımların yapılmasına imkân sağlayan bu parametre, inceleme alanında Türkiye koşullarındaki değeri göz önünde bulundurularak (Demirtaş 2003), 15 m olarak ayrılmış ve puanlanmıştır (Tablo 3; Şekil $4)$. 


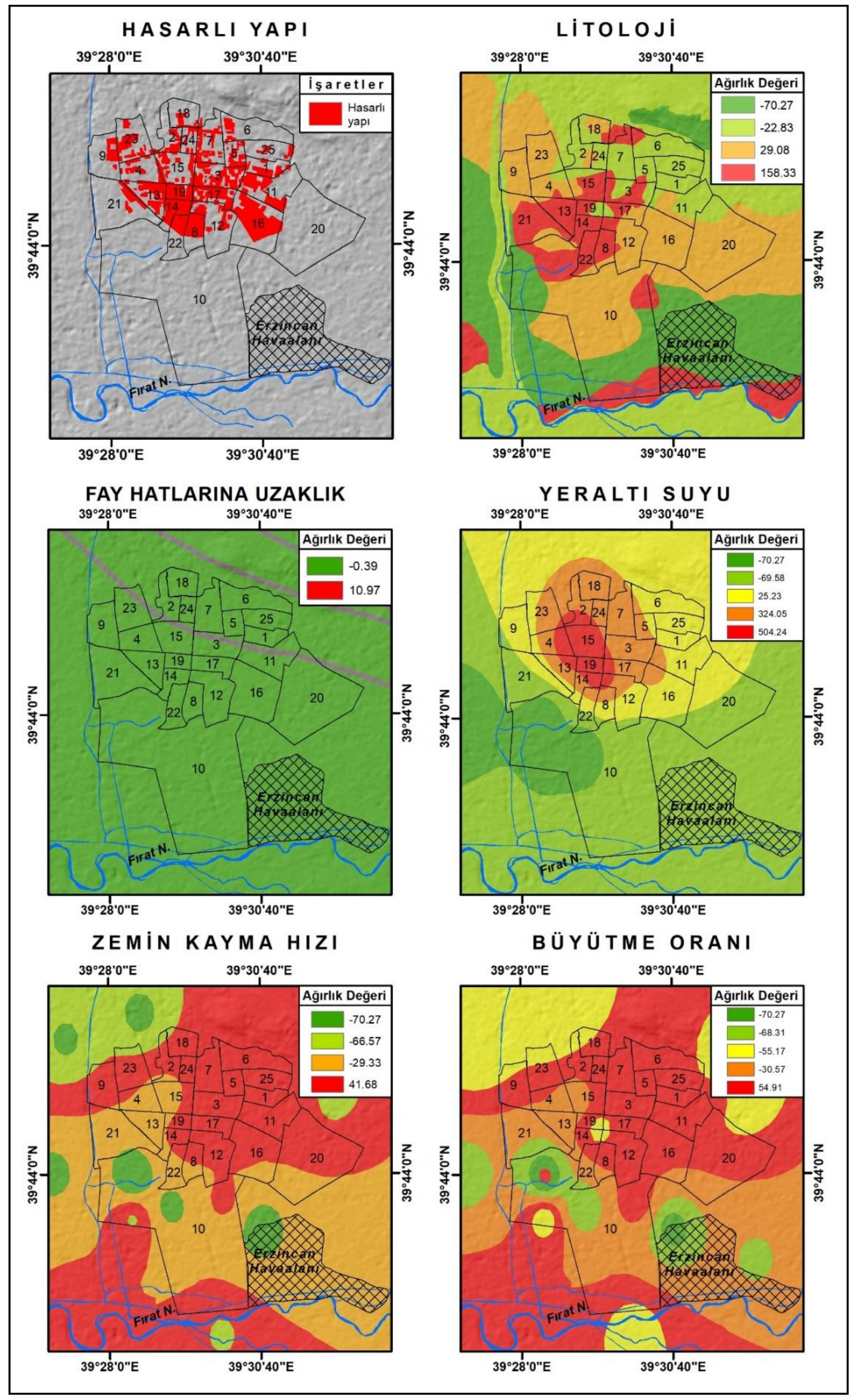

Şekil 4: Inceleme alanının yerel zemin parametre sınıflarına ait haritalar 
Yerel zemin koşullarından yeraltısuyu seviyesi, deprem duyarlılığını etkileyen önemli bir faktördür (Özşahin ve Değerliyurt 2013). Fırat Nehri’ne oldukça yakın ve genç alüvyal dolgulardan meydana gelen bir ova tabanında bulunan inceleme alanında, yeraltısuyu seviyesi çok yüksektir (Ada ve Ergin 1993). Bu durum herhangi bir deprem anında zemin sıvılaşmasına sebebiyet verebilir (Korkmaz 2006). Zira yapıların, suya doygun alüvyal zeminler üzerinde yer alıp almamalarının deprem duyarlılığı üzerinde belirleyici olduğunu bildirilmiştir (Turoğlu 2004). Nitekim Erzincan ve çevresinde depremlerin büyüklüğünden ziyade yeraltısuyu seviyesinin çok yüksek olması yüzünden maddi hasar ve insan kayıplarının artığı açıklanmıştır (Ada ve Ergin 1993). Bu bakımdan inceleme alanında, yeraltısuyu seviyesinin frekans oranları -20 m'den derin kesimlerde yükselmektedir. Frekans oranında izlenen değişimler -10 m'den sı̆̆ kesimlerde negatif ağırlık değeri göstermektedir (Tablo 3; Şekil 4).

Birçok araştırmacı tarafından farklı örnekler üzerinde denenerek deprem duyarlılığına etkisi test edilen zemin kayma hızı (Vs) (Tün 2013), deprem yükleri sırasında zemin tabakalarının meydana getireceği büyütmelerin hesaplanmasında kullanılan en önemli dinamik zemin parametrelerinden birisidir (Güllü 2013). İnceleme alanında zemin kayma hızı (30 m derinlikteki kayma dalgası hızları) 298-515 m/s arasındadır (Tablo 3). Bu faktöre ait en yüksek frekans oranı (0.11) ve pozitif yönlü tek ağırlık değeri (41.68) 400.01-450 m/s arasındaki kayma dalga hızının izlendiği sahalarda tespit edilmiştir (Tablo 3; Şekil 4). Diğer kayma dalga hızı sınıflarında ise negatif yönlü bir ilişkinin mevcut olduğu hesaplanmıştır. Bu durumun yerel zemin koşullarının deprem yer hareketleri üzerindeki etkilerini önemli kıldığı ve doğruladığı kaydedilmiştir (İyisan ve Ansal 1993).

İnceleme alanında deprem duyarlılığı bakımından etkili son faktör ise zemin büyütme oranıdır. İnceleme alanı için bu oran, Midorikawa yöntemi kullanılarak kayma dalga hızına göre hesaplanan değerlerden saptanmıştır (Dönmezçelik 2015). Elde edilen sonuçlara göre sahadaki büyütme oranı, 1.60 ve 2.22 değerleri arasında değişmektedir (Tablo 3). Bu faktöre ait en yüksek frekans oranı (0.13) ve pozitif yönlü tek ağırlık değeri (54.91) 1.8-1.9 sınıflarının yayılış gösterdiği sahalarda tespit edilmiştir (Tablo 3; Şekil 4). Zira zemin kayma hızıyla benzer etki gösteren zemin büyütme oranı, yüksek frekansta oranlara sahip sahalardaki yerel zemin koşullarının depreme daha duyarlı olduğuna işaret etmektedir (Lav ve Ansal 1993).

\subsection{Deprem Duyarlılık Analizi}

Çalışmada yapılan deprem duyarlılık analizi sonucunda günümüzde 95.596 kişinin yaşadığı Erzincan kentinin genel olarak orta ve yüksek duyarlılık sınıfları üzerinde yer aldığı tespit edilmiştir (Şekil 5; Tablo 4). Düşük deprem duyarlılığının hiç görülmediği bu sahada; çok yüksek duyarlılık \% 9.39 oranındadır. Kentsel alan ise genellikle çok yüksek duyarlılık değeri altında kalmaktadır (Şekil 5; Tablo 4). Bu durum, yaşanan depremlerin büyüklüğünden ziyade yeraltısuyu seviyesinin yüksek olması, ovadaki alüvyon kalınlığı ve bunların sıvılaşmaya etkisi gibi yerel zemin koşullarından kaynaklanmış olmalıdır.

Tablo 4: Inceleme alanının deprem duyarlılık sınıfları ve değerleri

\begin{tabular}{|l|c|c|c|}
\hline \multirow{2}{*}{ Deprem duyarlılık sınıfları } & \multirow{2}{*}{ Deprem duyarlılık değerleri } & \multicolumn{2}{c|}{ ALAN } \\
\cline { 3 - 4 } & & $\mathbf{k m}^{\mathbf{2}}$ & \% \\
\hline Düşük & $<--50$ & - & 55.84 \\
\hline Orta & $-50-0$ & 4624.40 & 34.77 \\
\hline Yüksek & $0-50$ & 2879.33 & 9.39 \\
\hline Çok yüksek & $50->$ & 777.27 & $\mathbf{1 0 0 . 0}$ \\
\hline \multicolumn{2}{|r}{} \\
\hline
\end{tabular}

Ada ve Ergin (1993), Erzincan kenti yerleşim alanında alüvyon kalınlığg ve karakteri (içindeki kil, silt, kum ve çakıl oranlarının) ile yeraltı su seviyesinin yüzeye yakın olmasının depremin şiddetinin daha fazla hissedilmesindeki başlıca etken olduğunu belirtmişlerdir. Ayrıca bu durumun can kaybı ve hasarın çok üzücü boyutlara ulaşmasına sebep olduğunu ifade etmişlerdir. Erken vd. (1993) Erzincan kentinin yerleştiği sahadaki zemin özellikleri ve hasar dağılımı karşılaştırıldığında gevşek karakterde kumlu siltli zeminlerin bulunduğu noktalarda betonarme yapılarda bile önemli bir hasarın meydana geldiğinin altını çizmiştir.

Askan vd. (2015a) tarafından yapılmış olasılıksal ve deterministik (senaryo) sismik tehlike analizlerinin sonuçları da, Erzincan kenti için sismik tehlike ve yapısal güvenlik ile ilgili ciddi sorunların bulunduğunu ve büyük bir deprem olmadan çözüm arayışına gidilmesi gerektiğini göstermiştir.

Diğer yandan olası bir deprem anında hasarın en az olacağı kesimler ise kentin batı ve güneybatı kesimindeki dağlık saha (Köhnem Dağı) doğrultusunda bulunan yerel zemin koşulları bakımından depreme orta derecede duyarlı alanlardır (Şekil 5; Tablo 4). Bu mekânlar, aynı zamanda inceleme alanı içindeki en güvenilir yerlerdir. 


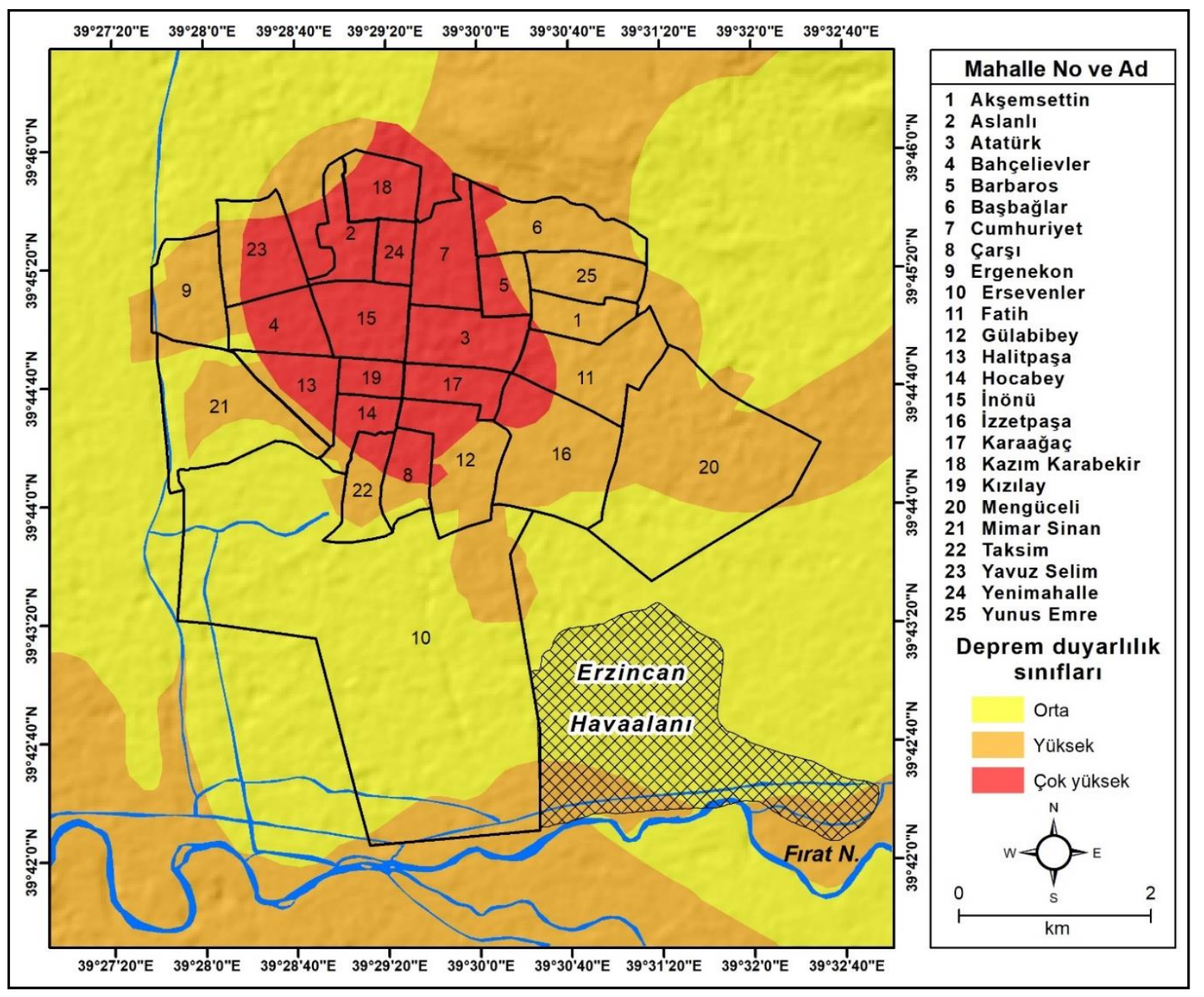

Şekil 5: Inceleme alanının deprem duyarlıık haritası

Erzincan kentinde deprem duyarlılık sınıflarının alansal dağılışı ise büyükten küçüğe doğru yüksek $\left(10481431 \mathrm{~m}^{2}\right)$, orta $\left(10235590 \mathrm{~m}^{2}\right)$ ve çok yüksek $\left(7178173 \mathrm{~m}^{2}\right)$ şeklindedir (Tablo 5). Deprem duyarlılığının çok yüksek olduğu mahalleler; Atatürk, İnönü, Karaağaç, Kızılay ve Yenimahalle'dir. Ayrıca Akşemsettin, Aslanlı, Barbaros, Cumhuriyet, Fatih, Halitpaşa, Kazım Karabekir ve Yunus Emre mahalleleri ise yüksek ve çok yüksek duyarlılık gösteren sahalarda kalmaktadırlar (Tablo 5).

Toplam nüfusun 95.596 kişi (2015) olduğu kentsel alanda nüfus yoğunluğu ise $292 \mathrm{kişi} / \mathrm{m}^{2}$ 'dir (Toplam kent alan1, $27885273 \mathrm{~m}^{2}$ ). Kentsel alanda görülen bu yoğun nüfus baskısı neticesinde kentsel nüfusun \% 50'si deprem duyarlılığının yüksek ve çok yüksek kategorisinde bulunduğu sahalarda ikamet etmesine yol açmıştır. Ayrıca kent nüfusunun \% 22 'si ise orta ve kısmen yüksek duyarlılı̆̆ın olduğu Ergenekon, Ersevenler, Mengüceli ve Mimar Sinan mahallelerinde yaşamaktadır (Şekil 5). Çalışma bulguları, Erzincan kenti dâhilinde hesaplanmış deprem ortalama hasar oranı haritalarına ait sonuç çıktıklarıyla (Şişman vd. 2013; Karimzadeh vd. 2015; Askan vd. 2015b) uyumludur (Şekil 6). Bu durum aynı zamanda çalışma kapsamında üretilmiş deprem duyarlılık haritasındaki verilerin de güvenilir olduğuna işaret etmektedir.

Tablo 5: Erzincan kenti mahallelerin nüfusları ve deprem duyarlılık sınıfları arasındaki ilişki (Mahalle adları Şekil 5’te verilmiştir)

\begin{tabular}{|c|c|c|c|c|c|}
\hline \multirow{2}{*}{ No } & \multirow{2}{*}{ Alanı (m) } & \multirow{2}{*}{ Nüfusu (kişi) } & \multicolumn{3}{|c|}{ Deprem duyarlılık sınıflarının alanı ( $\left.\mathbf{m}^{\mathbf{2}}\right)$} \\
\cline { 4 - 6 } & & & Orta & Yüksek & Çok yüksek \\
\hline 1 & 413505 & 2508 & & 404657 & 8848 \\
\hline 2 & 473215 & 5738 & & 57730 & 415485 \\
\hline 3 & 720749 & 5572 & & & 720749 \\
\hline 4 & 591586 & 3514 & 42062 & 56107 & 493417 \\
\hline 5 & 334832 & 1909 & & 117418 & 217414 \\
\hline 6 & 906855 & 4556 & 37875 & 702735 & 166245 \\
\hline 7 & 735960 & 6191 & & 2906 & 733054 \\
\hline
\end{tabular}


Tablo 5'in devamı

\begin{tabular}{|c|c|c|c|c|c|}
\hline \multirow{2}{*}{ No } & \multirow{2}{*}{ Alanı $\left(\mathbf{m}^{2}\right)$} & \multirow{2}{*}{ Nüfusu (kişi) } & \multicolumn{3}{|c|}{ Deprem duyarlılık sınıflarının alanı $\left(\mathrm{m}^{2}\right)$} \\
\hline & & & Orta & Yüksek & Çok yüksek \\
\hline 8 & 420901 & 2774 & 56695 & 132586 & 231620 \\
\hline 9 & 796330 & 6961 & 62322 & 734008 & \\
\hline 10 & 9418157 & 1096 & 7918851 & 1499306 & \\
\hline 11 & 1005645 & 3944 & & 817397 & 188248 \\
\hline 12 & 982452 & 1592 & 56235 & 581010 & 345207 \\
\hline 13 & 562913 & 2711 & & 160573 & 402340 \\
\hline 14 & 357038 & 1894 & 17999 & 58873 & 280165 \\
\hline 15 & 721193 & 4864 & & & 721193 \\
\hline 16 & 1471162 & 3061 & 180369 & 1057743 & 233050 \\
\hline 17 & 429681 & 437 & & & 429681 \\
\hline 18 & 508475 & 3880 & & 36832 & 471643 \\
\hline 19 & 258855 & 1527 & & & 258855 \\
\hline 20 & 3179018 & 4334 & 930761 & 2248257 & \\
\hline 21 & 1482249 & 8814 & 744487 & 737761 & \\
\hline 22 & 485156 & 1522 & 117187 & 248590 & 119379 \\
\hline 23 & 815947 & 7790 & 70745 & 265926 & 479276 \\
\hline 24 & 262304 & 2346 & & & 262304 \\
\hline 25 & 561015 & 6061 & & 561015 & \\
\hline TOPLAM & 27895193 & 95.596 & 10235590 & 10481431 & 7178173 \\
\hline
\end{tabular}

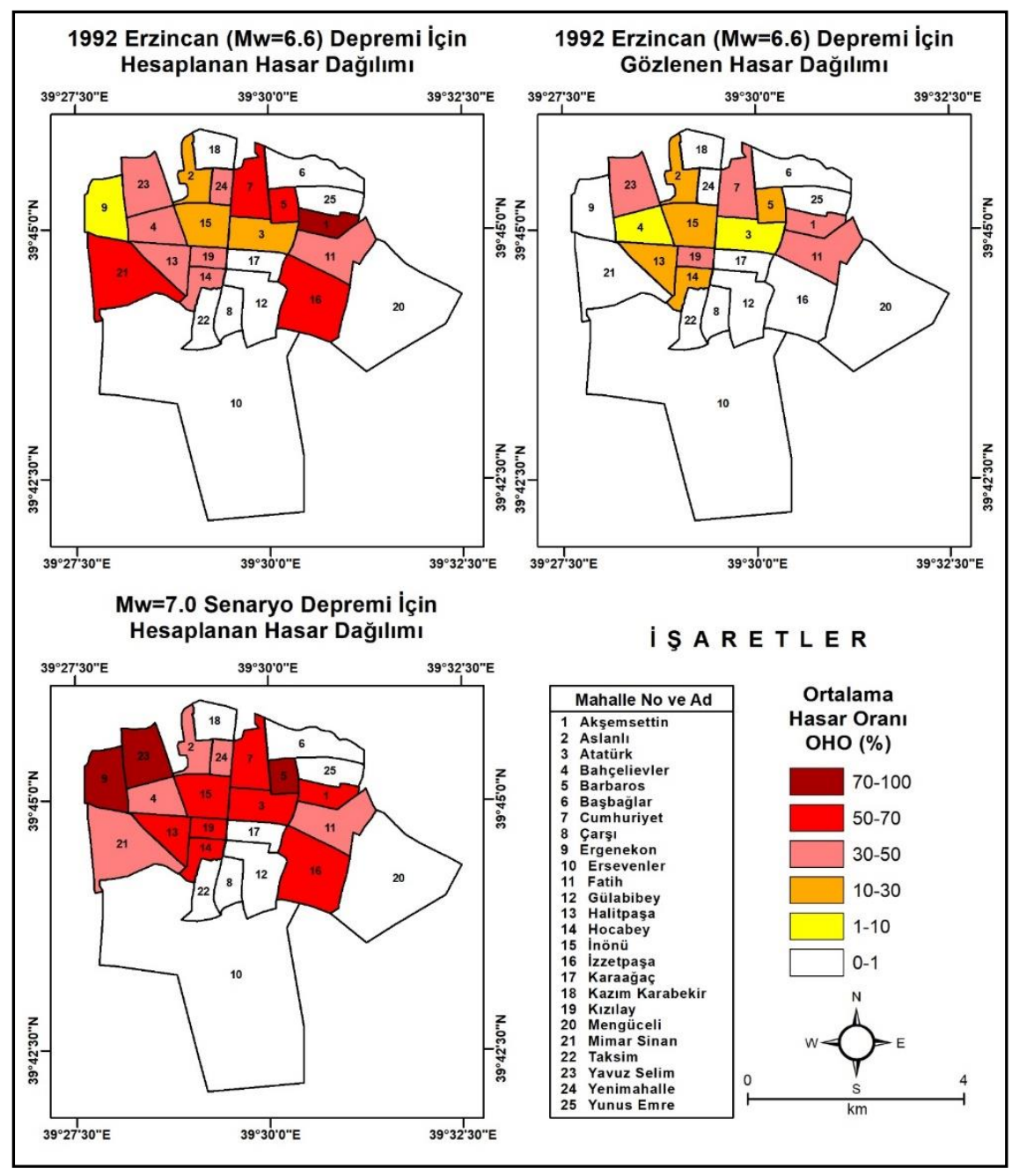

Şekil 6: Inceleme alanı için üretilmiş deprem ortalama hasar oranı haritaları (Askan vd. 2015b'den düzenlenerek) 
Elde edilen bulgulara dayanılarak kentsel gelişim doğrultusunun acilen kentin batı ve güneybatı kesiminde bulunan yerel zemin koşullarının daha kararlı ve uygun olduğu alanlara yönlendirilmesi gerektiği anlaşılmıştır (Şekil 7). Zaten kentin şimdiki yerinden taşınması konusunda ileri sürülen çeşitli görüşler de bu düşünceyi desteklemektedir. Nitekim kentin 1939 depreminden sonra Karayazı mevkiine, 1992 depreminden sonra da Erzincan Ovası'nın batısındaki Köhnem Dağı'nın ovaya bakan eteklerinde kurulmasına (Yalçınlar 1992) yönelik fikirlerin kentin şimdiki kuruluş yerine göre daha mantıklı bir yaklaşım olduğu ileri sürülmüştür (Şekil 7). Zira bu alanların gerek deprem şiddetinin azaltılması, gerekse verimli tarım alanlarının işgal edilmemesi bakımından daha müsait durumda olduğu vurgulanmıştır (Hayli 2002).

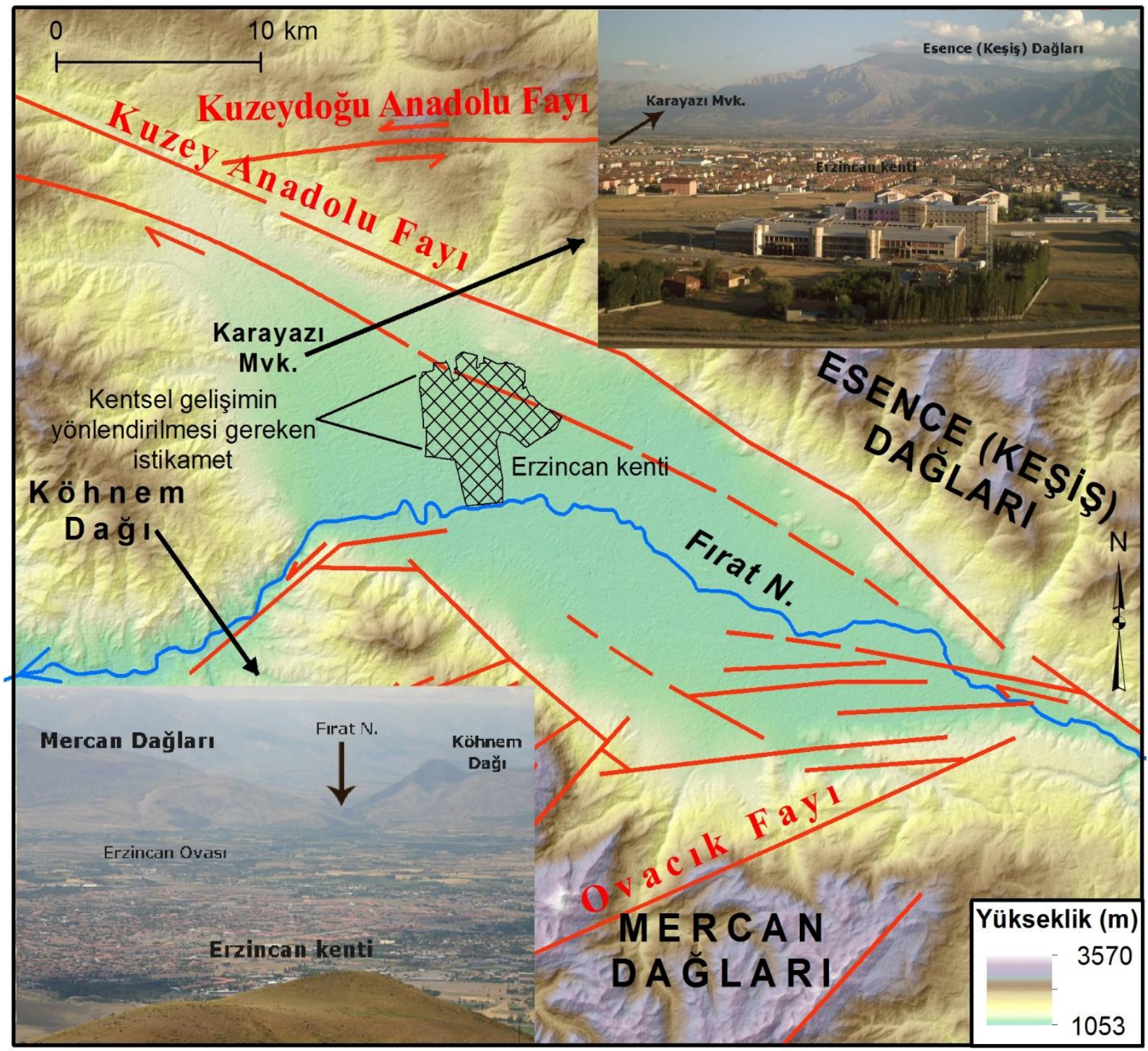

Şekil 7: Erzincan kentinin gelişim doğrultusunun yönlendirilmesi gereken doğrultu

Gelecekte yaşanacak depremlerin konumu, oluş zamanı, büyüklüğü ve diğer özellikleri belirsiz olduğu için, deprem duyarlılığı konusunda yapılan çalışmalar son birkaç on yıldır önemli bir karar verme aracı haline dönüşmüştür (Özşahin 2014). Özellikle deprem duyarlılık haritalarının üretilmesinde çok farklı değişkenler arasındaki ilişkinin pratik bir şekilde analizine izin veren CBS tekniklerinin kullanılması, konunun daha sağlıklı bir boyutta ele alınmasına öncülük etmiştir. $\mathrm{Bu}$ yüzden $\mathrm{CBS}$ tekniklerine dayalı yapılmış deprem duyarlılık çalışmaları olası bir deprem sonucunda meydana gelebilecek sonuçlar hakkında güvenilir bilgiler verdiği için temel uygulamalar olarak kabul edilmektedir (Mohamed vd. 2012). Yerel zemin koşullarına ait farklı değişkenler kullanılarak ve CBS teknikleriyle uyumlu yöntemden faydalanılarak hazırlanan bu çalışma sayesinde Erzincan kentinin deprem duyarlılık haritası üretilmiştir. Gerçekten de Turoğlu (2004) depreme karşı duyarlı alanların belirlenmesinde CBS teknolojilerinin desteklediği yöntemlerle duyarlılık analizlerinin yapılması gerektiğinin altını çizmiştir. Sonuçta kentsel alanda deprem duyarlılığının dağılımı konusunda mekânsal içerikli nicel bulgulara ulaşılmış ve sahanın büyük ölçekli modern bir deprem duyarlılık haritası elde edilmiştir. 
Çalışma bulgularıyla desteklenen bir diğer konu ise yerel zemin koşulları ve deprem yönetmelikleri arasındaki ilişkidir. İnceleme alanı ve deprem yönetmenliklerin Türkiye'deki miladı arasında çok manidar bir ilişki bulunmaktadır. Zira Türkiye'de ilk deprem yönetmeliği 1939 Erzincan depreminden sonra (1940) yürürlüğe girmiştir. Daha sonra 1942, 1947, 1968, 1975, 1997, 2007 yıllarında tekrar güncellenen bu yönetmenlikler, son olarak 2018 yılında çok köklü değişiklikler yapılmak suretiyle çağın gerekliliklere uygun şekilde yeniden düzenlenmiştir (Tunç ve Tanfener 2016). 18 Mart 2018 tarihli Resmi Gazetede yayınlanarak resmileşen 2018 deprem yönetmeliği, 01.01.2019 tarihinde yürürlüğe girecektir. Birçok değişikliğin yer aldığ bu yönetmenlikte yerel zemin özellikleriyle ilgili olarak daha önce yaygın bir şekilde kullanılan zemin sınıfları yeniden tanımlanmıştır. Eskiden binanın yerleştiği zemin katmanının yüksekliği göz önünde bulundurularak yapılan zemin sınıflandırması, yeni yönetmenlikte sahaya özel yerel zemin özelliklerinin belirlenmesine yönelik araştırma ve değerlendirme faaliyetlerini zorunlu hale getirmektedir. Dolayısıyla güncel yönetmenliğin doğrudan her sahanın kendine özgün yerel zemin özelliklerinin dikkate alınmasını gerekli kılacak şekilde düzenlendiği ve bu düzenlemenin de bilimsel anlamda daha doğru bir gelişme olduğu ifade edilebilir. Nitekim bu çalışmanın bulguları da yerel zemin özelliklerinin mekânsal bakımdan farklılık gösterdiğine işaret ettiği gibi aynı zamanda bu farklılıkların doğrudan deprem duyarlılı̆̆ üzerinde etkili olduğunu kanıtlamaktadır.

\section{Sonuçlar}

Çalışma sonucunda, Erzincan kentinin sismotektonik aktivitesi çok yoğun bir şekilde devam eden KAF zonunun etki alanı içinde yer aldığı ve yüksek oranda deprem tehdidi taşıdığı tespit edilmiştir. Kent tarihinde meydana gelmiş depremle ispat edilen bu yoğun sismik tehlike; litoloji, fay hatlarına uzaklık, yeraltısuyu seviyesi, zemin kayma hızı ve büyütme oranı gibi yerel zemin koşullarına bağlı olarak Erzincan kentinde farklı deprem duyarlılık sınıflarının belirmesine yol açmıştır.

Çalışma kapsamında gerçekleştirilen deprem duyarlılık analizi sonucunda Erzincan kentinin orta (\% 55.84) ve yüksek (\% 34.77) deprem duyarlılık sınıfları üzerinde yer aldığı belirlenmiştir. Özellikle kentsel alanın büyük bir kısmı, çok yüksek duyarlılık (\% 55.84) değerine sahip arazilerde yayılış göstermektedir. Ayrıca kentsel nüfusun \% 50'si deprem duyarlılığının yüksek ve çok yüksek olduğu mahallelerde ikamet etmektedir. Bu bulgular, sahadaki deprem duyarlılık dağılımının yaşanmış depremlerin büyüklüğünden ziyade doğrudan yerel zemin koşullarıyla alakalı olduğuna da işaret etmektedir. Olası bir deprem anında yerel zemin koşullarından kaynaklanabilecek hasar, deprem tehlikesinin orta derecede duyarlılık gösterdiği kentin çevresindeki alanlarda en az olacaktır. Bu yüzden kentin deprem olma potansiyeli dikkate alındığında, ivedilikle zemin şartlarının ıslahına yönelik önlemlerin alınması gerekmektedir. Bunun için yerel zemin koşullarını iyileştirici veya bu koşulların etkisiyle ortaya çıkabilecek hasarı asgari düzeye düşürebilecek girişimlerde bulunulabilir.

Öncelikle yeni inşa edilecek yapıların mevcut zemin koşulları dikkate alınarak kurulması gerekmektedir. Yine deprem duyarlılığı yüksek olduğu için tehdit altında bulunan mevcut yapılar üzerinde gerçekleştirilecek testlerle binaların sağlamlık durumları ölçülmeli, olası depremde düşük dayanıklılığa sahip yapılar güçlendirilmeli veya bu yapılar boşaltılmalıdır. Özellikle deprem duyarlılığı yüksek olan mahalleler için acilen müdahalede bulunulmalı veya kentsel dönüşüme tabi tutulmalıdır. Dolayısıyla kentsel gelişim doğrultusu daha uygun alanlara yönlendirilmelidir. Bu bakımdan yeni imar alanları belirlenirken, kentin batı ve güneybatı kesiminde kalan ve yerel zemin koşullarının olası depremlere karşı daha az duyarlı olduğu sahalar tercih edilmelidir. Ayrıca konu hakkında yapılacak planlama ve çalışmalarda güncel yöntem ve tekniklerin kullanılması ve deprem hasarını etkileyecek tüm bileşenlerin bütünlük içerisinde çözümlenmesi gerekmektedir. Bu bağlamda CBS tekniklerine dayalı yöntemlerden faydalanılması; hızlı, sağlıklı ve kullanılabilir sonuçlar üretilmesi bakımından oldukça önemlidir.

İnceleme alanından toplanacak daha detaylı ve yeni yersel verilerle duyarlılık analizinin tekrarlanması halinde, hem yakın sonuçlara ulaşılabileceği hem de benzer bir duyarlılık haritası elde edileceği tahmin edilmektedir. Zira çalışma kapsamında uygulanan deprem duyarlılık analizinde kullanılan parametreler, ne genel olarak çok kısa zamanda değişebilecek türden ne de deprem hasarını doğrudan büyütecek faktörler değillerdir. Bu parametreler yalnızca deprem hasarının artmasına destek olan faktörlerdir. Aslında inceleme alanında deprem duyarlılığını etkileyerek hasara yol açan asıl temel neden, gerek yukarıda bildirilen parametrelerin gerekse beşeri ihmallerin bileşkesi şeklinde ortaya çıkan olumsuz durumdur. Bu olumsuzluğun giderilmesi ancak daha akılcı ve bilimsel girişimlerle mümkündür. Diğer yandan çalışma kapsamında yapılan duyarlılık analizinin değişik yöntemlerle uygulanmasının başarı ve tahmin oranına yönelik daha farklı çıkarımlara götüreceği de düşünülmektedir. Dolayısıyla yerel zemin koşullarına bağlı gerçekleştirilen duyarlılık analizlerinin daha verimli olduğu söylenebilir.

Sonuç olarak kentlerin olası deprem afetine karşı sürdürülebilir şekilde planlanması, sismotektonik ve yerel zemin koşullarını dikkate alan sağlıklı çalışmaların yapılmasına bağlıdır.

\section{Teşekkür}

Bazı verilerin temininde verdiği destekten dolayı Sayın Kemal DÖNMEZÇELİK ve Özge ASLAN'a teşekkür ederiz. Ayrıca makalenin değerlendirme aşamasında değerli katkılar sağlayan tüm hakemlere teşekkür ederiz. 


\section{Kaynaklar}

Abul H.M., Ramachandram D., Mandava R., (2010), Bayesian belief network learning algorithms for modeling contextual relationships in natural imagery: A comparative study, Artificial Intelligence Review, 34, 291-308.

Ada E., Ergin N., (1993), Erzincan Yöresinin Depremselliğinin Yeraltı Koşullarına Göre Araştırılması ve Mart-1992 Depremlerinin Değerlendirilmesi, 2. Ulusal Deprem Mühendisliği Konferans1, 10-13 Mart 1993, İstanbul, Türkiye, ss.319-333.

Akıncı H., Doğan S., Kılıçoğlu C., (2011), Frekans Oranı Metodu Kullanılarak Samsun İl Merkezinin Heyelan Duyarlılık Haritasının Üretilmesi., TMMOB Harita ve Kadastro Mühendisleri Odas1 13. Türkiye Harita Bilimsel ve Teknik Kurultay1, 18-22 Nisan 2011, Ankara, Türkiye, ss.1-8.

Akkan E., (1964), Erzincan ovası ve çevresinin jeomorfolojisi, Ankara Üniv., DTCF Yay., Sayı:153, Ankara, Türkiye, 104ss.

Akpınar Z., Gürsoy H., Tatar O., Büyüksaraç A., Koçbulut F., Piper, J.D.A., (2016), Geophysical analysis of fault geometry and volcanic activity in the Erzincan basin, central Turkey: Complex evolution of a mature pull-apart basin, Journal of Asian Earth Sciences, 116, 97-114.

Anbazhagan P., (2013), Method for seismic microzonation with geotechnical aspects, Disaster Advances, 6(4), 66-86.

Askan A., Asten M., Erberik M.A., Erkman C., Karimzadeh S., Kılıç N., Şişman F.N., Yakut A., (2015a), Kentsel Alanlar İçin Bütünleşik Sismik Kayıp Tahmin Yöntemi: Erzincan Pilot Uygulaması., 3rd Turkish Conference on Earthquake Engineering and Seismology, 14-16 October 2015, İzmir, Turkey, ss.1-10.

Askan Gündoğan A., Asten M., Erberik A., Erkmen C., Karımzadeh S., Kılı̨̧ N., Şişman F.M., Yakut A., (2015b), Erzincan'da olası deprem hasarlarının belirlenmesi. Proje No: TUJJB-UDP-01-12, Türkiye Ulusal Jeodezi ve Jeofizik Birliği (TUJJB) Ulusal Deprem Program1, Ankara, Türkiye, 128ss.

Aslan Ö., (2015), 13 Mart 1992 Erzincan depremi yapısal hasarları üzerinde yerel zemin koşullarının etkisi, Yüksek Lisans Tezi, İstanbul Teknik Üniversitesi, İstanbul, Türkiye.

Barka A., (1993), Erzincan Baseni, Çevresinin Tektoniği ve 13 Mart 1992 Depremi, 2. Ulusal Deprem Mühendisliği Konferans1, 1013 Mart 1993, İstanbul, Türkiye., ss.259-270.

Cao C., Xu P., Wang Y., Chen J., Zheng L., Niu C., (2016), Flash flood hazard susceptibility mapping using frequency ratio and statistical index methods in coalmine subsidence areas, Sustainability, 8, 2-18.

Dă̆ S., Bulut F., (2012), Coğrafi bilgi sistemleri tabanlı heyelan duyarlılık haritalarının hazırlanmasına bir örnek: Çayeli (Rize, KD Türkiye), Jeoloji Mühendisliği Dergisi, 36(1), 35-62.

Dar J.A., Dubey R.K., (2015), Probabilistic seismic hazard analyses (PSHA) and liquefaction susceptibility evaluation of Kashmir Valley, India, The Proceedings of the National Academy of Sciences, India, Section A: Physical Sciences, 85(1), 177-186.

Değerliyurt M., (2013), Kentsel Gelişim ve Deprem Arasındaki İlişsinin İncelenmesine Bir Örnek: İskenderun (Hatay), 2. Türkiye Deprem Mühendisliği ve Sismoloji Konferans1, 25-27 Eylül 2013. Hatay, Türkiye, ss.1-6.

Değerliyurt M., (2015), Kent ve afet. Kent Çalışmaları II'nin İçinde (Karakuyu M., Keçeli A., Çelikoğlu Ş., Ed.), Pegem Akademi, Ankara, ss.251-272.

Demirtaş R., (2003), Yerleşim ve Yapı Güvenliği Açısından Diri Faylardan Ne Kadar Uzaklaşılmalı? (Antakya ve Osmaniye depremselliği ve kentleşmeye etkileri), TMMOB Konferanslar Serisi: 1, Jeoloji Odası Yayınları, No: 76, 26-27 Haziran 2003, Ankara, Türkiye, ss.1-12.

Dönmezçelik K., (2015), Erzincan ilinde imara açık alanda zemin büyütme analizleri hakkında bir araştırma, Yüksek Lisans Tezi, Atatürk Üniversitesi, Erzurum, Türkiye.

Erdik M., Demircioğlu M.B., Şeşetyan K., Hancılar U., (2011), Deprem risk belirlemesi, İstanbul Bülten,115, 8-20.

Erken A., Ansal A., Yıldırım H., Ülker R., (1993), Erzincan Kentinde Yerel Zemin Koşulları, 2. Ulusal Deprem Mühendisliği Konferans1, 10 Mart 1993, İstanbul, Türkiye, ss.355-362.

Erzincan Belediyesi, (2016), Erzincan kenti saylsal kent plant. Erzincan, Türkiye.

Eyidoğan H., (1993), 13 Mart 1992 Erzincan Depremi: Faylanma Mekanizmast ve Depremin Yeri Üzerine Bir Araştırma, 2. Ulusal Deprem Mühendisliği Konferans1, 10-13 Mart 1993, İstanbul, Türkiye., ss.292-299.

Gerçek D., Güven, İ.T., (2016), Kentsel dirençliliğin coğrafi bilgi sistemleri ile analizi: Deprem ve İzmit kenti, Harita Teknolojileri Elektronik Dergisi, 8(1), 51-64.

Gökkaya M.A., (2014), Coğrafi bilgi sistemleri (CBS) ve analitik hiyerarşi yöntemi (AHY) ile üretilen deprem tehlike haritalarının duyarlılık analizi, Yüksek Lisans Tezi, İstanbul Teknik Üniversitesi, İstanbul, Türkiye.

Gutierrez E., Taucer F., De Groeve T., Al-Khudhairy D.H.A., Zaldivar, J.M., (2005), Analysis of worldwide earthquake mortality using multivariate demographic and seismic data, American Journal of Epidemiology, 161(12), 1151-1158.

Güllü H., (2013), On the prediction of shear wave velocity at local site of strong ground motion stations: An application using artificial intelligence, Bulletin of Earthquake Engineering, 11(4), 969-997.

Harita Genel Komutanlığı (2015), I42b3, I42c2, I43a4, I43d1 numaralı 1:25.000 ölçekli topoğrafya haritaları, Harita Genel Komutanlığı, Ankara, Türkiye.

Hayli S., (2002), Erzincan ovasinda genel arazi kullanımı, Firat Üniversitesi Sosyal Bilimler Dergisi, 12(1), 1-24.

Hayli S., (2012), Az bilinen bir yerleşme tipi "Palangalar" ve Erzincan ovasında palanga yerleşmesi örnekleri, Türk Coğrafya Dergisi, $58,43-52$.

Isik, E., Kutanis, M., Bal, İ. E., (2016), Displacement of the Buildings According to Site-Specific Earthquake Spectra. Periodica Polytechnica, Civil Engineering, 60 (1), 37.

Işık, E., Kutanis, M., (2015), Determination of local site-specific spectra using probabilistic seismic hazard analysis for Bitlis Province, Turkey, Earth Sciences Research Journal, 19 (2), 129-134.

İyisan, R., Ansal, A. (1993), Erzincan'da dinamik zemin özelliklerinin kuyu içi sismik yöntemlerle belirlenmesi, 2. Ulusal Deprem Mühendisliği Konferans1, 10-13 Mart 1993, İstanbul, Türkiye., ss.372-379.

Karimzadeh S., Askan A., Erberik M.A, Yakut A., (2015), Seismic Damage Assessment Using Synthetic Ground Motions: A Case Study For Erzincan., 3rd Turkish Conference on Earthquake Engineering and Seismology, 14-16 October 2015, İzmir, Türkiye, ss.1-10. 
Korkmaz H., (2006), Antakya'da zemin özellikleri ve deprem etkisi arasındaki ilişski, Ankara Üniversitesi Türkiye Coğrafya Araştırma ve Uygulama Merkezi Coğrafi Bilimler Dergisi, 4(2), 47-63.

Kurtuluş C., (1993), 13 Mart 1992 Erzincan Depremi ve Sonuçları, 2. Ulusal Deprem Mühendisliği Konferans1, 10 Mart 1993, İstanbul, Türkiye, ss.310-318.

Lav, A., Ansal A. (1993), Erzincan Depreminde Zemin Büyütmesi, 2. Ulusal Deprem Mühendisliği Konferans1, 10-13 Mart 1993, İstanbul, Türkiye., ss.363-371.

Liu J. G., Mason P. J., Yu E., Wu M-C., Tang C., Huang R., Liu H., (2012), GIS modelling of earthquake damage zones using satellite remote sensing and DEM data, Geomorphology, 139-140, 518-535.

Mc Guire R. K., (2001), Deterministic vs. probabilistic earthquake hazards and risks, Soil Dynamics And Earthquake Engineering, 21, 377-384.

Mohamed AE-EA., El-Hadidy M., Deif A., Abou E.K., (2012), Seismic hazard studies in Egypt, National Research Institute of Astronomy and Geophysics, 1, 119-140.

MTA, (2016), Türkiye jeoloji veri bankası 1/25.000 ölçekli sayısallaştırılmış jeoloji haritaları. Maden Tetkik ve Arama Genel Müdürlüğü, Ankara.

Ösna T., (2013), GIS tabanlı bir mamdani bulanık çıkarsama aracının geliştirimi ve heyelan duyarlılık haritası üretimine uygulanması, Yüksek Lisans Tezi, Hacettepe Üniversitesi, Ankara, Türkiye.

Özkan M.Y., (1992), Geoteknik irdelemeler, 13 Mart 1992 Erzincan Depremi Mühendislik Raporu. TMMOB (Türk Mühendis ve Mimar Odaları Birliği), Ankara, Türkiye.

Özşahin E., (2014), Coğrafi bilgi sistemleri (CBS) ve analitik hiyerarşi süreci (AHS) kullanılarak Tekirdă̆ ilinde deprem hasar riski analizi, Uluslararası İnsan Bilimleri Dergisi, 11(1), 861-879.

Özşahin E., (2015), Kent planlaması ve jeomorfoloji, Kent Çalışmaları II’nin İçinde, (Karakuyu M., Keçeli A., Çelikoğlu Ș., Ed.), Pegem Akademi, Ankara, ss.215-231.

Özşahin E., Değerliyurt M., (2013), Modeling of seismic hazard risk analysis in Antakya (Hatay, South Turkey) by using GIS, International Journal of Innovative Environmental Studies Research, 1(3), 31-54.

Özşahin E., Kaymaz Ç. K., (2015), CBS ve AHS Kullanılarak Doğal Çevre Bileşenleri Açısından Kentsel Mekânın Yerleşime Uygunluk Analizine Bir Örnek: Antakya (Hatay), Doğu Coğrafya Dergisi, 20 (33), 111-134.

Öztaş T., (1993), Erzincan Şehri Dolayının Mühendislik Jeolojisi Özelikleri, 2. Ulusal Deprem Mühendisliği Konferansı, 10 Mart 1993 , İstanbul, Türkiye, ss.281-291.

Park S., Choi C., Kim B., Kim J., (2013), Landslide susceptibility mapping using frequency ratio, analytic hierarchy process, logistic regression, and artificial neural network methods at the Inje Area, Korea, Environmental Earth Sciences, 68, 1443-1464.

Pham B.T., Bui D.T., Indra P., Dholakia M.B., (2015), Landslide susceptibility assessment at a part of Uttarakhand Himalaya, India using GIS - based statistical approach of frequency ratio method, International Journal of Engineering Research \& Technology, 4(11), 338-344.

Pradhan B., Lee S., (2010), Landslide susceptibility assessment and factor effect analysis: Backpropagation artificial neural networks and their comparison with frequency ratio and bivariate logistic regression modelling, Environmental Modelling \& Software, 25 , 747-759.

Regmi A.D., Devkota K.C., Yoshida K., Pradhan B., Pourghasemi H.R., Kumamoto T., Akgun A., (2014), Application of frequency ratio, statistical index, and weights-of-evidence models and their comparison in landslide susceptibility mapping in central Nepal Himalaya, The Arabian Journal of Geosciences, 7, 725-742.

Rozos D., Skilodimou H.D., Loupasakis C, Bathrellos G.D., (2013), Application of the revised universal soil loss equation model on landslide prevention. an example from N. Euboea (Evia) Island, Greece, Environmental Earth Sciences, 70, 3255-3266.

Stein S, Geller R.J., Liu M., (2012), Why earthquake hazard maps often fail and what to do about it, Tectonophysics, 562-563, 1-25.

Suarez J.C., Moya A., Martin-Ruiz S., Amado P.J., Grigahcene A., Garrido R., (2014), The frequency ratio method for seismic modelling of doradus stars II, The role of rotation. Astronomy \& Astrophysics, Manuscript no. 3114art, 1-13.

Süzen M.L., (2002), Data driven landslide hazard assessment using geographical information system and remote sensing, $\mathrm{PhD}$. Thesis, Middle East Technical University, Ankara, Türkiye.

Şen Z., (2011), Supervised fuzzy logic modelling for building earthquake hazard assessment, Expert Systems With Applications, 38, 14564-14573.

Şengezer B.S., (1993), 13 Mart 1992 Erzincan Kentinde Meydana Gelen Hasarın Mahallelere Göre Irdelenmesi, 2. Ulusal Deprem Mühendisliği Konferans1, 10 Mart 1993, İstanbul, Türkiye, ss.404-415.

Şişman F.N., Askan A., Asten M., (2013), Pasif Sismik Yöntemler İle Erzincan'da İki Boyutlu Hız Modeli, 2. Ulusal Deprem Mühendisliği ve Sismoloji Konferans1, 25-27 Eylül 2013, Hatay, Türkiye, ss.1-8.

Tohumcu P., Kılıç H., Özaydın K., (2003), Yerel zemin koşullarının depremler sırasında yapısal davranış üzerinde etkileri yönünden sinıflandirllması, Yıldız Teknik Üniversitesi Dergisi, 2003/4, 85-101.

Tunç, G., Tanfener, T., (2016), 2007 ve 2016 Türkiye Bina Deprem Yönetmeliklerinin Örneklerle Mukayesesi, 3. Ulusal Yap1 Kongresi ve Sergisi Teknik Tasarım, Güvenlik ve Erişilebilirlik Konferansı, 24-26 Kasım 2016, Ankara Türkiye, ss.1-13.

Turoğlu H., (2004), Zemin sıvılaşmasının 17 Ağustos 1999 depreminde Adapazarı'ndaki hasara etkisi, İstanbul Üniversitesi Edebiyat Fakültesi Coğrafya Bölümü Coğrafya Dergisi, 12, 63-74.

Tün M., (2013), Ölçülen Zemin Parametrelerinden Kayma Dalga Hız (Vs) Hesabında Bulanık Mantık Yaklaşımı, 2. Türkiye Deprem Mühendisliği ve Sismoloji Konferans1, 25-27 Eylül 2013, Hatay, Türkiye, ss.1-9.

Tüysüz O., (1993), Erzincan Çevresinin Jeolojisi ve Tektonik Evrimi, 2. Ulusal Deprem Mühendisliği Konferans1, 10-13 Mart 1993, İstanbul, Türkiye, ss.271-280.

URL-1, (2018), TUİK Adrese Dayalı Nüfus Kayıt Sistemi, Standart arama, https://biruni.tuik.gov.tr/medas, (Erișim 9 Nisan 2018).

Vakhshoori V., Zare M., (2016), Landslide susceptibility mapping by comparing weight of evidence, fuzzy logic, and frequency ratio methods, geomatics, Natural Hazards and Risk, 7(5), 1731-1752.

Wu T.Y., Cheungc J., Colec D., Fink J.N., (2014), The Christchurch earthquake stroke incidence study, Journal of Clinical Neuroscience, 21(3), 412-415. 
Yalcin A., Reis S., Aydinoglu A.C., Yomralioglu T.A., (2011), GIS-based comparative study of frequency ratio, analytical hierarchy process, bivariate statistics and logistics regression methods for landslide susceptibility mapping in Trabzon, NE Turkey, Catena, 85, 274-287.

Yalçınlar İ., (1992), Türkiye'de strüktüral ve jeomorfolojik gözlemler, Türkiye Coğrafya Dergisi, 27, 15-25. 